NBER WORKING PAPER SERIES

\title{
ECONOMIC PERFORMANCE AND WORK ACTIVITY IN SWEDEN AFTER THE CRISIS OF THE EARLY 1990S
}

\author{
Steven J. Davis \\ Magnus Henrekson \\ Working Paper 12768 \\ http://www.nber.org/papers/w12768
NATIONAL BUREAU OF ECONOMIC RESEARCH
1050 Massachusetts Avenue
Cambridge, MA 02138 \\ December 2006
}

We thank Robin Douhan, Martin Floden, Tino Sanandaji and participants in the September 2006 SNS/NBER Conference on "Reforming the Welfare State" for helpful comments, Erik Hurst for assistance with the American Time Use Survey, and Richard Rogerson for data on hours worked in a number of countries. Robin Douhan, Martin Olsson and Per Thulin provided excellent research assistance. We gratefully acknowledge financial support from the Jan Wallander and Tom Hedelius Foundation. Needless to say, we are responsible for any remaining errors and shortcomings. The views expressed herein are those of the author(s) and do not necessarily reflect the views of the National Bureau of Economic Research.

(C) 2006 by Steven J. Davis and Magnus Henrekson. All rights reserved. Short sections of text, not to exceed two paragraphs, may be quoted without explicit permission provided that full credit, including (C) notice, is given to the source. 
Economic Performance and Work Activity in Sweden after the Crisis of the Early 1990s

Steven J. Davis and Magnus Henrekson

NBER Working Paper No. 12768

December 2006

JEL No. D13,H30,J20,L52,O52

\begin{abstract}
$\underline{\text { ABSTRACT }}$
Following a severe contraction in the early 1990s, the Swedish economy accumulated a strong record of output growth coupled with a disappointing performance in the labor market. As of 2005, hours worked per person 20-64 years of age are 10.5 percent below the 1990 peak and a mere one percent above the 1993 trough. Employment rates tell a similar story. Our explanation for Sweden's weak performance with respect to market work activity highlights the role of high tax rates on labor income and consumption expenditures, wage-setting arrangements that compress relative wages, business tax policies that disfavor labor-intensive industries and technologies, and a variety of policies and institutional arrangements that disadvantage younger and smaller businesses. This last category includes tax policies that penalize wealth accumulation in the form of owner-operated businesses, a pension system that steers equity capital and loanable funds to large incumbent corporations, and legally mandated job-security provisions that weigh more heavily on smaller and younger businesses. We describe these features of the Swedish institutional setup and provide evidence of their consequences based largely on international comparisons.
\end{abstract}

Steven J. Davis

Graduate School of Business

The University of Chicago

5807 South Woodlawn Avenue

Chicago, IL 60637

and NBER

steve.davis@gsb.uchicago.edu

Magnus Henrekson

Research Institute of Industrial Economics

P.O. Box 55665

S-102 15 Stockholm Sweden

Magnus.Henrekson@riie.se 


\section{Introduction}

Ten studies comprising the NBER-SNS project on The Welfare State in Transition were completed in 1995. ${ }^{1}$ The project research team, ten American and ten Swedish economists, first gathered in Stockholm during the fall of 1992 amidst the worst crisis to hit the Swedish economy since the 1930s. Output fell sharply for the second year in a row in 1992, interest rates skyrocketed, and unemployment reached levels not seen for half a century. Moreover, as of the early 1990s, the long-term growth performance of the Swedish economy had been weak for more than two decades, leading to a sizable drop in per capita income relative to other advanced economies. This backdrop of immediate crisis and longer term stagnation fostered a strong sense of urgency in the research team, which undoubtedly contributed to the overall success of the project.

Looking back, it is clear that the Swedish economy turned around in 1993-94. Since then, growth has been impressive from a European perspective, and one must return to Sweden's golden age in the 1960s to find comparable rates of output growth. But these output gains came with a worrisome lack of job creation. Aggregate employment in 2005 was 5 percent off its 1990 level, despite a population increase of more than 5 percent. Hours worked per person 20-64 years old in 2005 were a mere 1 percent above their 1993 level and 10.5 percent below the 1990 level. This disappointing employment and hours performance is all the more striking in light of Sweden's strong record of output growth since 1993.

Our explanation for Sweden's weak performance with respect to market work activity stresses a particular cluster of institutions that shape "the social structure of payoffs" and the organization of productive activity. ${ }^{2}$ We describe these institutions and provide evidence on their consequences. We do not seek to provide an exhaustive characterization of Sweden's institutional setup, because a modern society has many formal and informal institutions that differ greatly in terms of economic significance. Hence, some judgement is required to identify and characterize the important institutions. To form a compelling analysis and interpretation of economic performance, this judgment must be backed by evidence.

One way to assess the significance of particular institutions is to investigate whether they explain notable outcome differences across countries and distinctive aspects of economic organization and performance within countries. We have pursued this approach in several studies, often with a focus on Sweden. ${ }^{3}$ Much of our previous work, including our original contribution to the NBER-SNS project, evaluates the consequences of Swedish institutions by comparing Swedish outcomes to those in the United States, a country with a very different institutional setup. Our earlier work also features many-country comparisons that treat Sweden and the United States as two among many points along an institutional or policy

\footnotetext{
1 The studies were published in Freeman, Topel and Swedenborg (1997).

2 The role of institutions has moved to the fore of mainstream explanations for economic performance, especially over the longer term. See, for example, North and Weingast (1989), Rodrik et al. (2004), Acemoglou et al. (2005) and Baumol (1990), from whom we borrow the term, "social structure of payoffs." As the first SNSNBER study made clear, the Swedish welfare state can be seen as an economic model, or system, defined by a particular mix of institutions. These institutions and the interactions among them are key determinants of economic performance. For instance, the combination of high marginal tax rates and narrow pre-tax wage dispersion discourages labor supply under the Swedish model, but this effect has been mitigated by making labor force participation a requirement for access to many highly subsidized services (Lindbeck 1982).

3 See Davis and Henrekson (1997, 1999, 2005a, 2005b), Davis and Rivera-Batiz (2006), Henrekson and Johansson (1999) and Henrekson and Jakobsson (2003).
} 
spectrum. Under both approaches, we relate distinctive aspects of the institutional setup in Sweden and other countries to a range of outcomes. Evidence that particular institutions affect outcomes in many countries or influence several different outcome variables in the directions implied by economic reasoning lends greater confidence to the view that they matter in a significant way.

In our choice of outcome variables, we also seek to shed light on the mechanisms by which particular institutions affect economic performance. For example, we investigate whether and how tax policies and wage-setting arrangements affect the allocation and use of capital and labor inputs. We also seek to reach rough judgments about the economic efficiency of these effects. To that end, we sometimes interpret U.S. outcomes as emerging from an institutional setup that yields a relatively efficient deployment of capital and labor inputs. Based on this premise, we find evidence that several aspects of Sweden's institutional setup encourage the misallocation of physical capital, less efficient organizational forms for carrying out productive activity, and an inefficient allocation of work time within the market sector and between the market and home sectors. Inferences of this sort do not prove that the U.S. institutional setup is superior to the Swedish setup, but they do highlight certain costs that should be weighed against benefits of the Swedish system.

Several elements of Sweden's institutional setup figure prominently in our explanation for its weak labor market performance: high tax rates on labor income and consumption expenditures, wage-setting arrangements that compress relative wages, business tax policies that disfavor labor-intensive industries and technologies, and a variety of policies and institutional arrangements that disadvantage younger and smaller businesses. This last category includes tax policies that penalize wealth accumulation in the form of individual and family-owned small businesses, a pension system that steers equity capital and loanable funds to large incumbent corporations, and legally mandated job-security provisions that weigh more heavily on smaller and younger businesses.

In the next section, we review the evolution of output and work activity in Sweden during recent decades and compare the Swedish experience to that of the United States and other countries. We highlight the anemic recovery of employment and hours worked in Sweden since 1993. Section 3 summarizes the main analyses and findings in our previous studies of institutional arrangements and their effects on national outcomes. We provide evidence that several aspects of the Swedish institutional setup hamper smaller and younger businesses and repress the growth of service-oriented industries that compete closely with home production and the black market. In Section 4, we consider institutional developments in Sweden since the early 1990s. We describe important aspects of these developments and offer some analysis of their potential consequences. Section 5 concludes.

\section{Swedish Output Growth and Work Activity}

\subsection{Output Growth}

Beginning in the mid to late 1960s, Swedish GDP growth slowed relative to earlier decades and relative to other rich countries. Income per capita fell from $3^{\text {rd }}$ or $4^{\text {th }}$ place among OECD countries in 1970 to $17^{\text {th }}$ place in 1993, dropping some twenty percentage points relative to the OECD average (Lindbeck 1997, Henrekson 2001). Since the 1993 trough, the Swedish growth record has greatly improved relative to the contemporaneous performance in 
other rich countries and relative to the previous two decades. As shown in Table 1, Sweden's output grew almost 3 percent per annum from 1994 to 2005, well above the average pace in the EU-15 and the OECD. In terms of per capita GDP growth, Sweden even outperformed the United States over this period. No doubt, rapid growth after 1993 partly reflects a rebound from an unusually deep contraction in the early 1990s. Nevertheless, the Swedish economy had not experienced such rapid growth on a sustained basis since the 1960s, a decade often seen as the golden age of the Swedish Model. ${ }^{4}$

Table 1 Real GDP growth in Sweden, the United States, the EU-15 and the OECD from 1994/95 to 2004/05 (percent p.a.).

\begin{tabular}{lcccc}
\hline & \multicolumn{2}{c}{ GDP } & \multicolumn{2}{c}{ GDP per capita } \\
& $1994-2005$ & 1995-2005 & 1994-2004 & 1995-2004 \\
\hline Sweden & 2.90 & 2.79 & 2.63 & 2.59 \\
United States & 3.32 & 3.26 & 2.19 & 2.13 \\
EU-15 & $2.29 *$ & $2.24^{*}$ & 2.00 & 1.94 \\
OECD & 2.77 & 2.72 & 1.83 & 1.78 \\
\hline
\end{tabular}

* Data for 1994/95-2004 used.

Source: OECD Economic Outlook (online: SourceOECD); data for EU-15 from EuroStat (online).

Sweden's rapid growth in recent years has not translated into comparable gains in relative income. Following Lindbeck (1997), Figure 1 shows PPP-adjusted GDP per capita in Sweden relative to the average for 23 rich OECD countries from 1950 to 2004. Real income began to decline relative to other rich countries in the mid 1960s and continued to decline for nearly three decades, reaching a low point in 1993. Since then, Sweden's relative income rose by four percentage points, considerably less than one might expect from the positive growth differential in Table 1. The modest gain in Sweden's real income position reflects deterioration in its terms of trade (Håkansson and Lindbeck 2005).

Figure 1 Purchasing Power Parity Adjusted GDP per Capita in Sweden as a Percentage of the OECD Average according to the Penn World Tables (1950-92) and OECD Statistics (1970-2004).

\section{Enclosed}

Note: The OECD figures are for Lindbeck’s (1997) “23 rich OECD countries”, which exclude Mexico, Turkey, Poland, South Korea, Hungary and the Czech Republic. The OECD statistics concern current PPPs, while the Penn World Tables (PWT) concerns fixed PPPs in 1985 dollars (variable: RGDPCH). The PWT comparison has been achieved by a population-weighting of the income levels in the respective countries, and then the resulting series has been scaled so that the 1970 level is identical to the level of the OECD series in 1970.

Source: Penn World Tables and OECD, National Accounts (online: SourceOECD), June 2005.

The industry composition of Swedish output growth in recent years is also noteworthy. As reported in Table 2, manufacturing accounts for 41 percent of the real output gains in Sweden's market economy from 1994 to $2005 .{ }^{5}$ Nearly half of the output growth within

\footnotetext{
4 The average GDP growth rate in Sweden was 4.10 percent in 1966-70, 5.2 percent in 1961-65 and 3.4 percent in 1951-60 (Statistics Sweden).

5 When measuring GDP from the production side Statistics Sweden calls this "Total market producers and producers for own final use". This roughly corresponds to total production excluding government production. However, it should be noted that incorporated production units wholly owned by the government such as the
} 
manufacturing took place in Electrical and optical products. This aspect of Swedish output growth is particularly striking in light of manufacturing's falling share of output and, especially, employment in the world's rich countries in recent decades. The terms-of-trade deterioration noted above has probably helped stimulate the growth of Sweden's manufacturing output (measured at constant prices).

Table 2 Decomposition of Swedish Nongovernment GDP Growth, 1994-2005.

\begin{tabular}{|c|c|c|c|}
\hline & $\begin{array}{r}\text { Share of total } \\
\text { value added, } \\
\%, 1994\end{array}$ & $\begin{array}{r}\text { Value added } \\
\text { growth, \% } \\
1994-2005\end{array}$ & $\begin{array}{r}\text { Contribution to } \\
\text { total real value } \\
\text { added growth, } \\
1994-2005 \\
\end{array}$ \\
\hline Total market producers and producers for own final use & 100.0 & 49.7 & 49.7 \\
\hline Producers of goods & 40.9 & 63.0 & 21.9 \\
\hline Producers of services & 59.1 & 41.4 & 23.4 \\
\hline Producers of goods & 40.9 & 63.0 & 21.9 \\
\hline Agriculture, forestry, fishing & 3.5 & -1.3 & 0.0 \\
\hline Mining and quarrying & 0.4 & 22.8 & 0.1 \\
\hline Manufacturing & 26.6 & 95.2 & 20.6 \\
\hline Electricity, gas and water works & 4.3 & 5.6 & 0.2 \\
\hline Construction industry & 6.1 & 13.9 & 0.8 \\
\hline Producers of services & 59.1 & 41.4 & 23.4 \\
\hline Wholesale and retail sale & 14.3 & 51.9 & 6.1 \\
\hline Hotels and restaurants & 1.8 & 35.5 & 0.6 \\
\hline Transport, storage and communication & 9.5 & 45.3 & 3.8 \\
\hline Financial institutions and insurance companies & 7.3 & 39.1 & 2.0 \\
\hline Real estate, renting and business service companies & 22.8 & 30.4 & 6.7 \\
\hline Educational, health and social work establishment & 1.6 & 88.3 & 1.5 \\
\hline Other community and personal service establishment & 1.8 & 51.6 & 1.0 \\
\hline Manufacturing & 26.6 & 95.2 & 20.6 \\
\hline Food product, beverage and tobacco industry & 2.3 & 14.7 & 0.3 \\
\hline Textiles, clothing and leather industry & 0.4 & -11.2 & 0.0 \\
\hline Wood and wood products & 1.2 & 82.7 & 0.8 \\
\hline Pulp and papers; publishers and printers & 4.3 & 6.6 & 0.2 \\
\hline Coke and petroleum products & 0.2 & 118.9 & 0.2 \\
\hline Chemicals & 2.6 & 113.6 & 2.3 \\
\hline Rubber and plastic products & 0.7 & 42.5 & 0.3 \\
\hline Other non-metallic mineral products & 0.6 & 17.0 & 0.1 \\
\hline Basic metals; fabricated metal products & 3.5 & 30.4 & 1.0 \\
\hline Machinery and equipment n.e.c. & 3.5 & 44.9 & 1.3 \\
\hline Electrical and optical products & 3.0 & 1164.9 & 9.7 \\
\hline Transport equipment & 3.6 & 121.1 & 3.0 \\
\hline Manufacturing industry n.e.c. & 0.6 & 31.1 & 0.2 \\
\hline
\end{tabular}

Note: Growth figures are based on constant prices, reference year 2000. Due to different weights and variations in the value added growth between industries, the subparts will not add up to the total market when accounting for the contribution to total real value added growth.

Source: Statistics Sweden (SCB).

postal service, housing owned and run by local governments, and incorporated public hospitals are classified as market producers. 
Outside manufacturing, the greatest contributions to the growth of Sweden's market economy occurred in trade, transportation and communication, real estate and business services. Output grew relatively rapidly in education, health and community and personal services, but from a very modest base. We will return to the performance of market-based services below in our analysis of Sweden's institutional setup.

\subsection{Market Work Activity}

Figure 2 displays cumulative changes in Sweden's employment and population since 1950. As stressed in our original study, the second half of the $20^{\text {th }}$ century saw almost no net job growth in Sweden's private sector, even though the working-age population expanded by roughly a million persons. In contrast, government employment grew more than one-for-one with the working-age population until 1990.

Figure 2 Cumulative Employment and Population Changes in Sweden, 1950-2005.

\section{Enclosed}

Source: Statistics Sweden and own calculations.

The early 1990s marked a pronounced departure from employment patterns in earlier decades in two respects. First, government and private employment fell sharply relative to the working-age population. The employment-population ratio fell by roughly ten percentage points within a few years, and the open unemployment rate soared to levels not seen since the Great Depression. Second, the partial employment recovery after 1993 occurs almost exclusively in the private sector. In fact, private sector employment exceeded its previous peak in Sweden by 2001, while government employment remains well below the levels of the 1980s. Private sector employment fell again after 2001, however, and aggregate employment remains well below its peak in 1990 .

Despite the impression given by Figure 2, the extent to which the Swedish private sector has rediscovered a capacity for job creation is unclear. Some of the measured gains in private sector employment reflect changes in legal form of organization rather than new job creation within the private sector. For example, when a regional government incorporates its hospitals, employment at these hospitals is reclassified into the private sector. As a somewhat different example, when a publicly funded private school substitutes for a municipal school, the effect is to boost measured employment in the private sector.

Turning to international comparisons, Figure 3 compares the Swedish employment record since 1970 to the record in the United States and the rest of the OECD. Relative to population, employment was much higher in Sweden until the deep contraction of the early 1990s. It then fell below the value in the United States and greatly narrowed the gap relative to the average of other countries in the OECD. As the figure shows, the longer term path of the employment-population ratio differs greatly between Sweden and the United States, and both differ from the average path in the rest of the OECD. 
Figure 3 Employment as a Share of Total Population in Sweden, the United States and the OECD, 1970-2005 (percent).

\author{
Enclosed
}

Note: The OECD series is a population weighted series. OECD consists of the 25 "original" OECD countries excluding the U.S. and Mexico.

Source: OECD, Economic Outlook (online: SourceOECD), June 2006.

Table 3 presents a breakdown of employment and employment growth in Sweden's nongovernment sector from 1994 to 2005 . Nongovernment employment grew by 11.3 percent, and all of the net gains occurred in the service sector. Sizable contributions to nongovernment employment growth occurred in Wholesale and retail trade, Real estate, renting and business services, and Education, health and social work. Manufacturing employment fell by 3 percent despite a 95 percent gain in real value added (Table 2).

Although widely studied, employment and unemployment statistics have serious limitations as measures of overall work activity. Definitions of employment and unemployment are seldom straightforward, and they change over time and differ among countries in ways that defy easy comparisons. As we now discuss, employment and unemployment data are especially problematic as measures of labor market performance and work activity levels in Sweden.

Official statistics for Sweden show high rates of employment in the working-age population. For example, Statistics Sweden reports an employment rate of 77 percent in 2004 for persons 20-64 years of age. This figure reflects many “employed" persons who are not actually working - including those on sick leave, some students and conscripts, some persons on unpaid leave, people on paid parental leave, and people on temporary leave to care for a sick child. Sickness leave, in particular, is a major source of absenteeism in the Swedish economy. Because official employment statistics make no adjustment for sickness leave and other factors just mentioned, they overstate Sweden's aggregate labor input. The OECD (2005, p. 82) estimates that the number of persons actually at work in Sweden is 10 percentage points lower than the "employment rate" for men and 15 percentage points lower for women.

Official unemployment measures in Sweden also paint an overly strong picture of labor market performance. The open unemployment rate in Sweden was 5.5 percent as of 2004, according to Statistics Sweden, but several more comprehensive measures of unemployment have been suggested. They generally include all or part of the following categories: people on sick leave, parental leave, leave to care for family members, and unpaid leave and participants in labor market programs, discouraged workers, people on welfare, and early retirees. It is virtually impossible to agree on an exact number, but expansive concepts of Swedish unemployment yield figures in the range of 18 to 24 percent of the labor force (Edling 2005). 
Table 3 Decomposition of Swedish Nongovernment Employment Change, 1994-2005.

\begin{tabular}{|c|c|c|c|}
\hline & $\begin{array}{r}\text { Share of } \\
\text { employment, } \\
1994\end{array}$ & $\begin{array}{l}\text { Employment } \\
\text { growth rate, } \\
\text { 1994-2005, \% }\end{array}$ & $\begin{array}{r}\text { Percentage of } \\
\text { employment } \\
\text { growth, } \\
1994-2005 \\
\end{array}$ \\
\hline $\begin{array}{l}\text { Total market producers and producers } \\
\text { for own final use }\end{array}$ & 100.00 & 11.30 & 11.30 \\
\hline Producers of goods & 42.0 & -1.9 & -0.8 \\
\hline Producers of services & 58.0 & 20.9 & 12.1 \\
\hline Producers of goods & 42.0 & -1.9 & -0.8 \\
\hline Agriculture, forestry, fishing & 5.2 & -26.4 & -1.4 \\
\hline Mining and quarrying & 0.3 & -1.1 & 0.0 \\
\hline Manufacturing & 27.2 & -3.0 & -0.8 \\
\hline Electricity, gas and water works & 1.2 & 15.2 & 0.2 \\
\hline Construction industry & 8.0 & 14.7 & 1.2 \\
\hline Producers of services & 58.0 & 20.9 & 12.1 \\
\hline Wholesale and retail sale & 20.1 & 7.1 & 1.4 \\
\hline Hotels and restaurants & 4.1 & 16.7 & 0.7 \\
\hline Transport, storage and communication & 10.3 & 0.5 & 0.1 \\
\hline $\begin{array}{l}\text { Financial institutions and insurance } \\
\text { companies }\end{array}$ & 3.2 & 6.0 & 0.2 \\
\hline $\begin{array}{l}\text { Real estate, renting and business service } \\
\text { companies } \\
\text { Educational, health and social work }\end{array}$ & 12.6 & 51.0 & 6.4 \\
\hline establishment & 3.3 & 77.6 & 2.6 \\
\hline $\begin{array}{l}\text { Other community and personal service } \\
\text { establishment }\end{array}$ & 4.4 & 16.8 & 0.7 \\
\hline Manufacturing & 27.2 & -3.0 & -0.8 \\
\hline Food product, beverage and tobacco & 2.6 & -15.0 & -0.4 \\
\hline Textiles, clothing and leather industry & 0.6 & -31.7 & -0.2 \\
\hline Wood and wood products & 1.4 & 2.7 & 0.0 \\
\hline Wood and wood products & 4.0 & -22.2 & -0.9 \\
\hline Pulp and papers; publishers and printers & 0.1 & -10.3 & 0.0 \\
\hline Coke and petroleum products & 1.3 & 3.0 & 0.0 \\
\hline Chemicals & 0.9 & 1.3 & 0.0 \\
\hline Rubber and plastic products & 0.7 & -16.4 & -0.1 \\
\hline Other non-metallic mineral products & 3.7 & 12.4 & 0.5 \\
\hline Basic metals; fabricated metal products & 3.6 & 3.1 & 0.1 \\
\hline Machinery and equipment n.e.c. & 3.1 & -9.8 & -0.3 \\
\hline Electrical and optical products & 3.2 & 21.5 & 0.7 \\
\hline Transport equipment & 2.1 & -12.5 & -0.3 \\
\hline
\end{tabular}

Note: The third column is calculated as the first column multiplied by the second and divided by 100 . Employment is defined as number of persons.

Source: Statistics Sweden (SCB) and own calculations.

As a broad measure of labor input, hours actually worked per person is a more useful indicator, and one that sidesteps some of the conceptual and measurement issues that arise with employment and unemployment measures. At a minimum, hours-based measures of work activity shed additional light on the behavior of aggregate labor inputs. Motivated by these remarks, Figure 4 displays the evolution of average hours worked in Sweden since 
1990. ${ }^{6}$ Hours worked per person 16-64 years old fell by 11 percent from 1990 to 1993 (from 1325 to 1178 hours). The recovery from 1993 to 2005 is only a tiny 8 hours. Hours worked per person of working age in 2004 are 10.5 percent below the level of 1990 .

Figure 4 Average Annual Hours Worked in Sweden, 1990-2005.

\section{Enclosed}

Source: Statistics Sweden.

The data on hours worked in Figure 4 derive from self-reported measures in samples of persons. As of 2004, average reported hours of work per employed person is 1,630. This figure may well be an overstatement, given the incidence of part-time work, sick-leave absenteeism, parental leave, training, etc. among those counted as employed in Sweden. Some support for this view comes from a survey of 500 firms collected by the Confederation of Swedish Employers. According to this source, the average number of actual hours worked among full-time employees in the private sector is 1,554 hours in $2005 .{ }^{7}$ In comparison, the average of self-reported hours worked for all employees in 2004 is about 5 percent higher. In this regard, it should be noted that absenteeism of every kind as well as part-time work is more prevalent in the public sector. Additional evidence comes from OECD estimates for average hours by full-year equivalent workers in 2002, accounting for various kinds of absences. According to OECD (2005, Table 4.1), the estimate for Sweden is only 1349 hours, dramatically lower than self-reported hours. (The corresponding European average is 1567 work hours.) In short, these comparisons suggest that official statistics substantially overstate market work activity in Sweden.

Figure 5 shows average hours per person of working age from 1956 to 2003 in Sweden and the United States. ${ }^{8}$ Average work time evolves along remarkably different paths in the two countries, with Americans working much less than Swedes in the 1950s and much more by the 1990s. Among Swedes 15-64 years of age, work time fell by more than 200 hours per year from 1956 to 1972. Swedish work time then fluctuated in a narrow band for 15 years, before recovering somewhat in the late 1980s and plummeting to new lows in the 1990s. Hours per working-age Swede dropped by 11.5 percent from 1261 in 1990 to 1116 in 1993. In contrast, average hours among working-age Americans rose rapidly from 1179 in 1982 to 1413 in 2000, and then fell sharply after 2000 from a very high base. According to these data, Americans spend 150 hours more per year in market work activity than Swedes as of 2003.

\footnotetext{
${ }^{6}$ Measures of hours worked are also subject to errors and interpretation difficulties. In this regard, we note that Statistics Sweden revised their estimates of the annual number of hours worked per employed person upward in the early 2000s. For example, the figure for 1997 (as reported in the OECD Employment Outlook) was revised upward by 78 hours.

${ }^{7}$ See Svenskt Näringslivs Tidsanvändningsstatistik, a quarterly publication. The data on work and absenteeism cover 200,000 employees at 500 firms with roughly 2500 establishments. Reporting firms have chosen to participate, so the response rate is 100 percent.

${ }^{8}$ We rely on international data on average hours worked per person of working age supplied by Rogerson (2006), who compiled the data from OECD sources and from data made available by the Groningen Growth and Development Center at http://www.ggdc.net/index-dseries.html\#top. The Groningen data on annual hours worked are "intended to include paid overtime and exclude paid hours that are not worked due to sickness, vacation and holidays, etc." Nevertheless, since the Groningen data rely heavily on official national sources, they are subject to the same concerns expressed in the text regarding inaccurate reports of hours actually worked. These concerns apply to the data for all countries, but they may be more serious for Sweden.
} 
Figure 5 Average Hours Worked Per Person 15-64, 1956-2003, Sweden and the United States.

\section{Enclosed}

Source: Rogerson (2006), as compiled from OECD sources and the Groningen Growth and Development Center.

Large national differences in the level and time path of average hours worked hold more broadly among rich countries, as Rogerson (2006) effectively highlights. Compared to other rich countries, the United States experienced unusually large gains in average hours worked after the early 1980s, but Australia, Canada and New Zealand had similar experiences. Austria, Denmark, Finland, Portugal and the United Kingdom, among other countries, experienced large declines in average work time from high levels in the 1950s and 1960s, much like Sweden. Average hours fell even more sharply in Germany, France and Italy. They fell by smaller amounts from higher starting points in Switzerland and Japan. Greece, Ireland, the Netherlands and Spain experienced large increases in average work hours after the late 1980s, partly reversing declines in previous decades. The overall picture is one of remarkable heterogeneity among rich countries in the evolution of average work time.

Figure 6 displays the joint evolution of average work hours and per capita output in Sweden and the United States. The prevailing longer term pattern in Sweden is one of output gains accompanied by decreases in average work hours. In sharp contrast, the prevailing pattern in the United States is one of output gains accompanied by increases in average hours. Judging by the experience of these two countries in recent decades, there is no natural tendency for the amount of time devoted to market work activity to either rise or fall as per capita output rises. Instead, the long term response of market work activity appears to depend greatly on country-specific features.

Figure 6 The Joint Evolution of Average Work Hours and Per Capita Output in Sweden and the United States, 1960-2003.

\section{Enclosed}

Note: Average hours is average annual hours worked among persons 15-64 years of age. Real output is measured in 2000 SEK and USD, respectively.

Source: Authors' calculations on data from Rogerson (2006) and OECD sources.

\subsection{Time Use Surveys}

The preceding section draws on standard sources for data on employment and hours worked in the market sector. Time use surveys allow for a broader view of work activity that includes time devoted to (unpaid) work activity outside the market sector. We draw on evidence from time use surveys to briefly address three questions. First, how much time do Swedish and American adults devote to work activity outside the market sector? Second, how does the composition of time spent outside paid employment differ between the two countries? Third, how do trends in the amount of time devoted to overall work activity compare to those for market work activity? 
Table 4 Time Use Breakdown, Sweden and the United States Compared.

\begin{tabular}{|c|c|c|c|c|}
\hline \multirow{2}{*}{$\begin{array}{c}\text { Men and Women, 20-74 Years Old } \\
\text { Time-Use Category }\end{array}$} & \multicolumn{2}{|c|}{ Hours Per Day } & \multicolumn{2}{|c|}{$\begin{array}{c}\text { U.S.-Swedish } \\
\text { Difference }\end{array}$} \\
\hline & $\begin{array}{r}\text { U.S. } \\
(2004)\end{array}$ & $\begin{array}{r}\text { Sweden } \\
(2000-2001)\end{array}$ & $\begin{array}{r}\text { Hours per } \\
\text { day }\end{array}$ & $\begin{array}{r}\text { Hours per } \\
\text { year }\end{array}$ \\
\hline 1. Study & 0.21 & 0.28 & -0.07 & \\
\hline 2. Travel (excluding travel during work) & 1.30 & 1.44 & -0.15 & \\
\hline 2.a. Commuting to and from work & 0.32 & 0.33 & -0.01 & \\
\hline 3. Free Time & 15.51 & 15.55 & -0.04 & -13 \\
\hline 3.a. Personal Care & 10.29 & 10.43 & -0.14 & \\
\hline 3.b. Leisure Activities & 5.22 & 5.12 & 0.10 & 37 \\
\hline 4. Work & 6.38 & 6.26 & 0.12 & 43 \\
\hline 4.a. Paid Employment & 3.90 & 3.53 & 0.38 & 138 \\
\hline 4.b. Domestic Work (excluding child care) & 2.47 & 2.73 & -0.26 & -95 \\
\hline Food prep, dishwashing & 0.55 & 0.89 & -0.35 & -126 \\
\hline Cleaning dwelling & 0.36 & 0.38 & -0.02 & \\
\hline Laundry & 0.20 & 0.17 & 0.03 & \\
\hline Construction and repairs, gardening, pets & 0.56 & 0.59 & -0.03 & -12 \\
\hline Shopping and services & 0.53 & 0.43 & 0.10 & 35 \\
\hline Other & 0.28 & 0.27 & 0.01 & \\
\hline 5. Child Care (Unpaid) & 0.50 & 0.38 & 0.13 & 47 \\
\hline 6. Unspecified Time Use & 0.11 & 0.10 & 0.00 & \\
\hline Domestic Work + Child Care & 2.98 & 3.11 & -0.13 & -48 \\
\hline Leisure Activities + Child Care & 5.72 & 5.49 & 0.23 & 84 \\
\hline
\end{tabular}

Note: Personal care includes sleep, eating and other personal care activities. Leisure includes unpaid volunteer work outside the household and care of adults who do not reside in the household. Large breaks at work (e.g., time spent on lunch break) are classified as part of paid employment under work-related activities, but short breaks are treated differently for the two countries. They are classified as work time for Sweden and as leisure time for the United States.

Sources: Sweden: Harmonised European Time Use Survey (HETUS) Pocketbook at http://forum.europa.eu.int/Public/irc/dsis/tus/library?l=/comparable_statistics/sweden_25_01xls/_EN_1.0_\&a=d. United States: authors' calculations on micro data from the American Time Use Survey, available at http://www.bls.gov/tus/datafiles_2004.htm.

Table 4 addresses the first two questions, drawing on time use data for persons between 20 and 74 years of age in Sweden (2000-2001) and the United States (2004). On average, Americans spend 138 more hours per year in paid employment than Swedes according to the time use data, very similar to the extra 150 hours per year according to labor force surveys (Figure 5). However, Swedes spend an extra 95 hours per year in domestic household work, excluding child care. In other words, the U.S.-Swedish difference in time spent on overall work activity, inclusive of domestic household work, is less than one-third the difference in time devoted to paid employment. ${ }^{9}$ If unpaid child care is treated as part of domestic work activity, then the extra time devoted by Swedes to nonmarket work activity falls by half.

\footnotetext{
${ }^{9}$ Olovsson (2004) reaches a similar conclusion from tabulations in Juster and Stafford (1991) of time devoted to nonmarket work activity in Sweden and the United States in the 1980s.
} 
Remarkably, Table 4 indicates that Americans enjoy more leisure time than Swedes - an extra 37 hours per year, and an extra 84 hours per year if unpaid child care is treated as leisure. Another striking feature of the comparison pertains to time devoted to meals in the domestic household sector. Swedes spend an extra 126 hours per year, roughly 2.4 hours per week, on food preparation and cleanup. These patterns in the data are consistent with a theory of tax effects on task assignment and time allocation described in Section 3.2 below. They are also consistent with evidence described below of how taxes on consumption expenditures and labor income alter the mix of market production activities.

Turning to trends in time use, Aguiar and Hurst (2006) document changes in time devoted to leisure and work activity from 1965 to 2003 by Americans aged 21 to 65, excluding students and early retirees. They find very large increases in leisure time of 6 to 9 hours per week for men and 4 to 8 hours per week for women. The precise figure depends on the exact definition of leisure and the variables used to control for shifts in demographic structure. Among men, the rise in leisure mainly reflects a decline in time devoted to paid employment. Among women, it reflects a large decline in time devoted to domestic work that more than offsets rising time in paid employment. Total work time, paid employment plus domestic work, declined by about 8 hours per week for both men and women over the period covered by their study. In sum, working-age Americans enjoyed large gains in leisure time after 1965 with no decline in time devoted to paid employment (Figure 5). Since Americans spend a larger portion of their adult years in retirement now than in decades past, the gains in leisure time among all adults are even larger than suggested by the findings of Aguiar and Hurst. We are unaware of a comparable study for Sweden, but Statistics Norway reports very similar trends in time use from 1971 to 2000. ${ }^{10}$

\subsection{Summary}

We summarize the main points of this section. First, despite Sweden's rapid output growth since 1993, there has been little net job creation and almost no gain in market work hours per person. Swedes 16-64 years old spend 10 percent fewer hours in market work activity than in 1990. Second, Sweden has experienced a considerable shift away from public sector employment since 1990. It is unclear how much of this shift reflects newly created jobs in the private sector rather than a reclassification of existing employment positions. Third, the time path of market work hours is strikingly different in Sweden and the United States over the past several decades. Fifty years ago, Swedes spent 200 more hours per year than Americans in market work activity; today, they spend 150 fewer hours. Fourth, broader measures of work activity that encompass time spent on unpaid domestic work show a much smaller gap between Swedes and Americans. Based on a comparison of recent time use surveys, we find that American adults spend an extra 43 hours per year in overall work activity. Swedes spend considerably more time than Americans in unpaid domestic work, especially food preparation and cleanup, and Americans actually enjoy greater leisure time.

\section{Main Thesis and Lessons from Earlier Work}

Our earlier work holds that institutional arrangements strongly influence national economic performance. In line with this broad thesis, we develop several pieces of evidence

\footnotetext{
10 At http://www.ssb.no/english/subjects/00/02/20/tidsbruk_en/.
} 
and analysis that country-specific institutional arrangements have important effects on work activity, industry structure, activity shares of smaller and younger businesses, and the size of the underground economy.

\subsection{The Role of Wage-Setting Institutions}

Sweden has a compressed wage structure compared to most other rich countries. That is, Sweden has relatively narrow wage gaps between men and women and relatively small wage differentials by industry, education, experience and tenure on the job. Wage inequality among observationally similar workers is also low in Sweden. As discussed in Davis and Henrekson (2005b), much evidence points to Swedish wage-setting arrangements as a major reason for its compressed wage structure.

The evidence that wage-setting arrangements help shape the Swedish wage structure leads naturally to questions about their role in determining other outcomes. For example, how do labor market institutions that compress wage differentials affect the industry distribution of employment? The economic logic behind this question is straightforward: If relative wages influence the allocation of workers and cooperating factors of production, then institutional forces that compress wage differentials also affect the structure of employment. To address this question, some of our earlier work examines the evolution of Sweden's industry distribution of employment from 1960 to 1994 and compares it to the U.S. distribution over the same period. Specifically, we relate the evolution of U.S.-Swedish differences in the industry distribution of employment to the structure of relative wages between and within industries.

In Davis and Henrekson (2005b), we find that centralized wage setting pushed the Swedish employment distribution in three directions: away from low-wage industries, away from high-wage industries, and away from industries with high wage dispersion among workers. In other words, centralized wage-setting arrangements compressed the wage distribution, and as a consequence, steered the employment structure towards middle-wage jobs. These effects intensified as centralized wage setting spread through the Swedish economy after the 1950s, and they reversed after the dissolution of centralized wage setting commenced in 1983. The estimated effects of centralized wage setting in Davis and Henrekson (2005b) are large, at their peak accounting for 40 percent of U.S.-Swedish differences in industry structure. They also account for much of the evolution in the U.S.Swedish differences in industry structure between 1970 and 1994. Although wage-setting arrangements in Sweden are no longer so highly centralized, collective bargaining remains an important force for wage compression in many sectors. ${ }^{11}$

Institutional pressures for wage compression also disadvantage smaller businesses and shift the size distribution of employment toward larger businesses. Two observations support this claim. First, an extensive literature consistently finds higher wages at larger employers, even after exhaustive efforts to control for observable worker characteristics and other job attributes. ${ }^{12}$ This strong empirical regularity implies that wage compression on the employer

\footnotetext{
${ }^{11}$ For a systematic review of the evidence that collective bargaining tends to compress wage differentials, see Blau and Kahn (1999).

12 Oi and Idson (1999) review the evidence in this regard.
} 
size dimension raises relative labor costs for smaller employers. ${ }^{13}$ Second, the available evidence also indicates that residual wage dispersion is greater at smaller employers. In a study of the U.S. manufacturing sector, Davis and Haltiwanger (1996) find a pronounced negative relationship between employer size and wage dispersion among workers after conditioning on education, experience and gender. Lallemand and Rycx (2005) find the same pattern for a broader set of industries in Belgium, Ireland, Italy and Spain. This pattern suggests that standard rate compensation policies, which closely tie wages to readily observed characteristics of workers and jobs, are less advantageous or more costly for smaller employers. Hence, the strong tendency for collective bargaining and centralized wage-setting arrangements to produce standard rate compensation structures works to the disadvantage of smaller employers.

Partly motivated by this reasoning, Davis and Henrekson $(1997,1999)$ investigate the size distribution of business activity in Sweden. By a variety of measures, large firms play a bigger role in Sweden than in most other European countries. In addition, compared to the United States, the Swedish employment distribution tilts away from industries with a more important role for smaller firms and establishments. These patterns in the data are consistent with the view that institutional pressures for wage compression disfavor smaller businesses, but, as we discuss below, other aspects of Sweden's institutional setup also work to the disadvantage of smaller businesses.

\subsection{Tax Burdens on Consumption and Labor}

Taxes on labor income and consumption expenditures encourage substitution from the legal market sector to home production and the underground economy. To appreciate the power of taxes to depress employment and distort production decisions, consider the choice between market provision and home production in the simple case with no capital inputs. The household opts for the least-cost source of supply. In the absence of taxes, we can express the household's decision rule as

$$
\text { Choose market provision if: } W^{B} H^{B}>W^{P} H^{P} \Leftrightarrow \frac{W^{B} H^{B}}{W^{P} H^{P}}>1 \text {, }
$$

where $W^{P}$ is the wage rate of the professional supplier in the market, $H^{P}$ is the production time required by the professional, $W^{B}$ is the opportunity cost of household time, and $H^{B}$ is the time input required in household production. According to (1), the law of comparative advantage governs the choice of production sector. The household opts for self supply when it has comparative advantage at the production activity in question and for market provision when the professional has comparative advantage. This decision rule is socially efficient in the sense of minimizing the value of scarce time resources used up in production.

Taxes break this link between privately optimal decisions and socially efficient outcomes. To see this point, let $t$ denote the tax rate on the household's labor income, let $s$ denote the

\footnotetext{
13 However, Albaek et al. (1998) find an hourly wage elasticity with respect to plant size for Sweden that is similar to the elasticity for the United States. This result is surprising to us, because numerous empirical studies find that Sweden's wage structure is highly compressed relative to the U.S. wage structure on other dimensions. In addition, international studies by Teulings and Hartog (1998) and Lallemand et al. (2005) find that the magnitude of the size-wage elasticity declines with the degree of centralization and coordination in wage setting.
} 
payroll tax rate on the professional's compensation, and let $m$ denote the tax rate on consumption expenditures. The decision rule for the choice of production sector becomes

$$
\text { Choose market provision if: } \frac{W^{B}}{W^{H}} \frac{H^{B}}{H^{P}}>\frac{(1+s)(1+m)}{1-t} \text {. }
$$

As seen in (2), higher tax rates raise the threshold comparative advantage ratio at which the market solution dominates. The private choice of production sector is now governed by a taxdistorted law of comparative advantage. ${ }^{14}$ Too few tasks are carried out in the market sector because of taxes, and too little time is spent working in the market. Conversely, too many tasks are carried out in the household (or underground) sector, and too much time is spent working outside the formal market sector.

As tax rates rise, marginal producers in the market sector are displaced by less efficient producers in the household sector. This displacement effect lowers average productivity computed over the market and household sectors, but it raises official productivity measures because they do not encompass the household sector. ${ }^{15}$ Hence, the displacement effect also leads official statistics to overstate true productivity in high-tax societies relative to that of low-tax societies. This effect operates even when all workers have the same productivity and earnings ability in market-based activities. Thus, the productivity effect identified here is distinct from the idea that the tax and transfer system has bigger disemployment effects on the least productive workers.

To asses whether tax rates in the relevant range significantly alter the composition of market-based activity, Davis and Henrekson (2005a) consider fourteen rich countries with comparable data on tax rates and the industry distribution of market activity. They identify tax-sensitive industries on a priori grounds, then investigate whether such industries have lower employment and output shares in high-tax countries. As seen in Figure 7, employment and output shares are markedly lower in a broad group of tax-sensitive industries that includes retail trade, hotels and restaurants, and consumer repair services. ${ }^{16}$ An increase in the taxdistorted comparative advantage ratio by 25 basis points lowers the employment share in this industry group by 2.4 percentage points, or 12 percent of industry employment evaluated at the mean. Similarly, a 25 basis point rise lowers the value-added share by an estimated 1.9 points (13 percent). Davis and Henrekson also find that the share of market activity accounted for by eating, drinking and lodging establishments is twice as sensitive to taxes as the broader industry group considered in Figure 7. In contrast, the share of employment in manufacturing shows a positive, statistically insignificant relationship to the tax-distorted comparative advantage ratio. These cross-country patterns support the view that taxes on labor and

\footnotetext{
14 Davis and Henrekson (2005a) derive analogous decision rules when production requires capital and labor.

15 If firms differ in their ability to evade taxes, then taxes need not crowd out the least productive firms. In this case, taxes can lower average productivity and raise average pre-tax production costs within the formal market sector. See Palda (1998) for an analysis of this issue. Strand (2005) analyzes the efficiency consequences of taxation in a model with three production sectors - the above-ground market economy, the black-market economy and production for own use in the household. He also provides an extensive set of references to other work on the efficiency effects of income and consumption taxes in models with taxed and untaxed production sectors.

16 Domestic household help, child care services and personal services are probably among the most tax-sensitive activities, but they are excluded in Figure 7 because these activities are not classified in the same way across countries, or because they are not reported at a sufficiently disaggregated level. In addition, several countries provide sizable subsidies for child care services that are not captured by our tax measures.
} 
consumption distort the choice of production sector and, in the process, depress employment in the formal market economy.

Figure 7 Tax Burdens and the Share of Measured Activity in Trade, Eating, Drinking, Lodging and Consumer Repair Services, 14 Rich Countries in 1995.

\section{Enclosed}

Source: Reproduced from Davis and Henrekson (2005a).

Note: Each panel shows a scatter plot and an ordinary least squares regression line with standard error of the slope coefficient in parentheses. See Davis and Henrekson (2005a) for details regarding the data and the calculation of the tax-distorted comparative advantage ratios.

These results also help to explain certain aspects of Sweden's industry structure. In particular, compared to countries with lower tax burdens on consumption expenditures and labor income - e.g., Canada, Ireland, Switzerland, the United Kingdom and the United States - Sweden has small employment and output shares in retail trade, consumer repair services, and eating, drinking and lodging establishments. Production activity is relatively labor intensive in these industries and relatively easy to substitute between the market sector and home production (or the underground sector). Hence, high tax burdens push production activity in these industries out of the (legal) market sector. This interpretation finds additional support in Table 4, which shows that Swedes devote considerably more time to domestic household work, especially meal preparation and dish washing, than Americans.

Another type of evidence on tax-induced displacements of employment and production is available from official adjustments to Swedish GDP accounts. Statistics Sweden now makes upward adjustments to official measures of GDP in an effort to capture unrecorded black market activity. These adjustments go back to 1993 and they are largely based on an inquiry carried out in 1997 by the National Audit Office (1997). Table 5 reports the official adjustments by industry in 1996. The largest adjustments are for Auto repair, Restaurants, Taxi services and Hairdressing, and the smallest are for Industry and Consulting. These patterns are consistent with the hypothesis that high tax rates and burdensome regulations shift the mix of (above-ground) market production away from labor-intensive activities (e.g., Restaurants and Hairdressing) and toward capital-intensive and skill-intensive activities (e.g., Industry and Consulting). A new comprehensive inquiry conducted in 2005-06 and published by the Swedish National Tax Board (2006) found results consistent with 1997 study. Total black market work is estimated at 4-5 percent of GDP. ${ }^{17}$ An estimated 13 percent of all persons aged 18-74 engaged in black market work within the previous year, an increase of 2 percentage points compared to the 1997 study. Hours worked in the black market are estimated to have increased in roughly the same proportion. ${ }^{18}$

\footnotetext{
${ }^{17}$ Indirect methods for estimating the size of the black market economy in Sweden tend to produce much larger numbers. See, for example, Table 4.3 in Schneider and Enste (2002).

18 More specifically, a special inquiry into the underreporting of revenue in Restaurants indicates an increase in black market activity in recent years: "The Swedish National Tax Board estimates, based on an extensive audit of the restaurant industry in the county of Dalecarlia, that the unreported revenue in the restaurant industry in 1995 nationwide amounted to 37 percent of total revenues of 20 billion kronor, or approximately 7 billion kronor. The degree of tax evasion has subsequently accelerated. More recent estimates suggest that unreported revenues amount to roughly double in 2002, i.e. 15 billion kronor.” (Skattestatistisk Årsbok 2004, p. 238; authors' translation). 15 billion kronor amounts to 102 percent of total value added in Restaurants in 2002 according to the National Accounts.
} 
Table 5 Adjustments to Official GDP for Black Market Activity by Statistics Sweden, 1996.

\begin{tabular}{lr}
\hline Industry & $\begin{array}{r}\text { Black Market Activity, \% } \\
\text { of Recorded Value Added }\end{array}$ \\
\hline Agriculture & 6.4 \\
Forestry & 8.5 \\
Industry & 0.3 \\
Construction & 10.4 \\
Auto repair & 26.4 \\
Restaurants & 16.2 \\
Taxi services & 19.2 \\
Freight hauling & 15.8 \\
Consulting & 4.0 \\
Cleaning & 5.2 \\
Gambling & 6.6 \\
Hairdressing & 34.8 \\
Other & 4.5 \\
\hline
\end{tabular}

Source: SOU 2002:113.

Our cross-country investigation in Davis and Henrekson (2005a) also finds that higher tax rates on labor income and consumption expenditures lead to less work activity in the formal market sector as a whole and to a larger underground economy. ${ }^{19}$ Consider, for example, a 12.8 percentage point difference in the tax rate between two countries, which amounts to a unit standard deviation in the cross section of countries. Using data for the mid-1990s and our preferred specification, we estimate that a tax increase of this size leads to 122 fewer hours worked per adult per year in the formal market sector, a drop of 4.9 percentage points in the employment-population ratio, and a rise in the underground economy equal to 3.8 percent of GDP. Evaluating at means in our cross-country sample, the implied elasticity of aggregate hours worked with respect to the combined tax rate on labor and consumption is -0.55 . As we explain in our earlier work, our estimates reflect the direct effect of taxes on labor supply and labor demand plus the effects of tax-funded welfare and social insurance programs on labor supply incentives.

Taxes on labor income and consumption expenditures also alter relative labor demands among workers in a potentially important manner. Tax-sensitive industries include eating and drinking establishments, laundry and cleaning services, child care, consumer repair services, domestic household help, and most personal services. As suggested by this list, tax-sensitive sectors tend to rely heavily on less skilled workers with lower schooling and wages. Hence, uniform tax rates on labor income and consumption expenditures have disproportionately large negative effects on the demand for less skilled workers, depressing their relative wages and employment opportunities.

The interaction of wage-setting institutions and high tax rates is also important in the Swedish case. Institutions that compress pre-tax wages reinforce tax-induced distortions in the

\footnotetext{
${ }^{19}$ Many other studies investigate the role of tax rates in cross-country differences in work activity and the size of the underground economy. Several recent studies in this area are motivated by the provocative work of Prescott (2004). See Alesina et al. (2005), Davis and Henrekson (2005a), and Rogerson (2006) for references to this literature.
} 
choice between market provision and home production. To see this point, consider first the impact of institutional forces that raise wages for less-skilled, lower wage workers. As we just remarked, activities with easy substitution between home and market production rely heavily on less-skilled workers in the production process. Hence, wage floors for less-skilled workers raise the cost of production by a larger percentage in activities with easier substitution between home and market production. In this respect, wage floors for less-skilled workers reinforce the departures from comparative advantage induced by taxes on labor and consumption. Second, institutional forces that reduce wages for skilled workers affect their choice between home production and market provision in the same way as higher labor income taxes. In this respect, too, labor market institutions that compress pre-tax wage differentials reinforce tax-induced departures from the law of comparative advantage in the choice of production sector.

\subsection{Other Policies that Influence Ownership, Financing and Hiring}

The preceding discussion indicates that Sweden's compressed wage structure and high tax burdens on labor and consumption disadvantage smaller businesses and depress employment and output in industries that compete closely with the black market or unpaid household production. Our earlier work also identifies several other aspects of the Swedish institutional setup with similar effects on the size and industry distribution of employment and production. We briefly discuss these features in the balance of this section.

\section{Corporate Tax Policy}

Beginning in the early 1960s, and continuing for three decades, effective tax rates on business income in Sweden differed tremendously by source of finance and ownership category. Debt was the most tax-favored form of financing, and new equity issues were the most penalized. Business ownership positions held directly by individuals and families were taxed much more heavily than other ownership categories. To illustrate the magnitude of these differences, Table 6 presents effective marginal tax rates for different combinations of owners and sources of finance. Three categories of owners and three sources of finance are identified. The effective marginal tax rates are calculated assuming a 10 percent pre-tax real rate of return, an asset holding period of ten years, and an asset composition that matches the actual composition in manufacturing. A negative entry in Table 6 means that the real rate of return is greater after tax than before tax.

Differences in effective tax rates on Swedish business income were especially large around 1980. For example, a debt-financed business investment in 1980 offering a pre-tax real return of 10 percent yielded an after-tax return of 18.3 percent for a tax-exempt institution such as a pension fund. The same business investment financed by a new equity issue purchased directly by households yielded an after-tax real return of -3.7 per cent. More generally, debt financing was highly favored by the tax system throughout the period covered by Table 6, and direct household ownership positions were heavily disfavored. King and Fullerton (1984) and Fukao and Hanazaki (1987) find that Swedish tax policy was extreme in these respects compared to other countries. Furthermore, the Swedish tax system generally subsidized housing investment, while simultaneously discouraging direct business ownership.

These differences in effective tax rates have potentially powerful effects on the organization of business activity and the industry mix of productive activity. A few examples serve to make this point. First, to the extent that debt financing is less costly and more readily 
available for larger and better established firms, high statutory tax rates coupled with taxdeductible interest payments work to the disadvantage of smaller firms and potential entrants. As we explain below, Swedish credit market policies hampered access to debt financing by younger and less established firms. Second, debt financing is more easily available to firms with ready forms of collateral. Hence, firms and sectors that intensively utilize physical capital reap greater benefits from tax code provisions that favor debt financing. This aspect of the tax system favors capital-intensive industries and modes of production relative to laborintensive ones. Indeed, Södersten (1984) provides evidence that, beginning in the 1960s, effective marginal tax rates on business income in manufacturing fell considerably relative to most other industries. Third, high tax rates on business income accruing directly to households represses many of the same activities as high tax rates on labor and consumption. Many economic activities that are highly substitutable between market provision and home production (e.g., cooking, cleaning, laundering, landscaping, home repairs) offer greater than average scope for self employment, employment in small firms, start-ups, and family-owned businesses. Hence, high effective tax rates on business income accruing directly to households works against a vibrant entrepreneurial and small-firm sector.

Table 6 Effective Marginal Tax Rates on Business Income in Sweden by Ownership Category and Source of Financing, 1960, 1970, 1980, 1985, 1991.

\begin{tabular}{lrrr}
\hline & Debt & $\begin{array}{r}\text { New share } \\
\text { issues }\end{array}$ & $\begin{array}{r}\text { Retained } \\
\text { earnings }\end{array}$ \\
\hline $\mathbf{1 9 6 0}$ & & & \\
Households & 27.2 & 92.7 & 48.2 \\
Tax exempt institutions & -32.2 & 31.4 & 31.2 \\
Insurance companies & -21.7 & 41.6 & 34.0 \\
$\mathbf{1 9 7 0}$ & & & \\
Households & 51.3 & 122.1 & 57.1 \\
Tax exempt institutions & -64.8 & 15.9 & 32.7 \\
Insurance companies & -45.1 & 42.4 & 41.2 \\
1980 & & & \\
Households & 58.2 & 136.6 & 51.9 \\
Tax exempt institutions & -83.4 & -11.6 & 11.2 \\
Insurance companies & -54.9 & 38.4 & 28.7 \\
1985 & & & \\
Households & 46.6 & 112.1 & 64.0 \\
Tax exempt institutions & -46.8 & 6.8 & 28.7 \\
Insurance companies & -26.5 & 32.2 & 36.3 \\
1991 & & & \\
Households & 31.7 & 61.8 & 54.2 \\
Tax exempt institutions & -9.4 & 4.0 & 18.7 \\
Insurance companies & 14.4 & 33.3 & 31.6 \\
\hline
\end{tabular}

Note: The calculations assume a real pre-tax return of 10 percent, an asset holding period of 10 years, an asset composition identical to the actual composition in the manufacturing sector, and the following inflation rates: 3 percent in 1960, 7 percent in 1970, 9.4 percent in 1980, and 5 percent 1985 and 1991. The calculations conform to the general framework developed by King and Fullerton (1984).

Source: Jan Södersten, see also Södersten $(1984,1993)$. 


\section{Credit Market Policy}

The Swedish credit market was highly regulated throughout the postwar period until the late 1980s. Priority was given for lending to the public sector and housing. The credit volume to other sectors was generally subjected to quantitative restrictions and the rate of interest was also regulated, which resulted in a situation of virtually continuous credit rationing (SOU 1982:52; Jonung, 1994). This set of regulations clearly favored credit access by larger, older, well-established firms and by capital-intensive firms with ready sources of collateral.

\section{$\underline{\text { Savings Policies }}$}

Sweden's mandatory national pension system (ATP) instituted in 1960 transformed the public sector into the most important supplier of credit. Large surpluses were accumulated in the national pension funds, the so-called AP funds. By the early 1970s, the AP funds accounted for 35 per cent of total credit supply (Pontusson 1992). The institutionalization of savings benefited large, well-established firms with good credit ratings and the ability to operate with high debt-equity ratios. The gradual introduction of mandatory supplementary pension schemes reinforced this effect. ${ }^{20}$ Moreover, the very high marginal tax rates on individual income - the top marginal rate was close to 90 per cent in the early 1980s - in combination with fully tax-deductible pension contributions created a strong incentive for individuals to channel savings to large institutions (as a rule highly regulated) and thus reduced the supply of equity financing for potential entrepreneurs and extant small businesses.

Since the availability of equity financing is a critical factor for both startups and rapidly expanding young businesses (Blanchflower and Oswald 1998; Lindh and Ohlsson 1996; Holtz-Eakin et al., 1994), the low rate of personal savings in Sweden probably hampered startups and high-growth young firms. ${ }^{21}$

\section{Labor Market Regulations}

New labor market regulations in the 1970s gave organized labor a greater influence on corporate decision making. The Codetermination Act of 1976 mandated union representation on corporate boards of directors (Pontusson 1992). The Employment Security Act (LAS) of 1974 gave employees extensive protection against dismissal. The only legal grounds for dismissal under the act are gross misconduct and redundancies. In the latter case, LAS stipulates a "last in - first out principle." Strict employment security provisions are probably costlier for smaller and younger firms because their employment levels are more volatile. Both the rate at which workers separate from jobs and the rate at which employers destroy job positions decline with the size, age and capital intensity of the employer. ${ }^{22}$ These patterns in worker separation and job destruction rates suggest that any costs imposed by the LAS fall more heavily on younger, smaller and less capital-intensive businesses and shift the distribution of market activity towards industries characterized by longer job tenures and relatively stable employment at the level of individual businesses.

\footnotetext{
20 The AP fund system also benefited incumbents through the so-called "lending back" system (återlån) based on the rule that employers were allowed to borrow up to half the amount they had paid in to the fund during the previous year. The potential for using this credit channel was therefore proportional to the firm's wage bill in the previous year. This type of lending was abolished in 1987.

${ }^{21}$ See also Cressy and Olofsson (1997) and further studies cited in Henrekson and Jakobsson (2005), which find that small and medium-size Swedish firms have a preference for financing expansion with retained earnings or equity supplied by the original owners relative to debt financing and equity from new sources.

22 For evidence regarding these patterns in the United States, see Brown and Medoff (1989), Davis, Haltiwanger and Schuh (1996), and Davis et al. (2006).
} 
Government Monopolization of Production

By 1990, the public sector accounted for more than one third of total employment in Sweden. The expansion of public sector employment from 1950 to 1990 resulted from political decisions to produce many income-elastic services such as health care, care for the elderly, child care and higher education almost entirely in the public sector. Over time, these political decisions had a profound impact on the character of business activity in the private sector. In particular, the production of many services that might have been supplied by the self employed and by small business organizations was instead supplied by the state. In line with this claim, Davis and Henrekson (1999) report that Sweden had the lowest rate of self employment among OECD countries in the 1970s and 1980s, an unusually high share of employment in larger firms compared to other European countries, and an unusually high concentration of corporate ownership and control.

\subsection{Summary}

Key features of the Swedish institutional setup have depressed market work activity and hampered smaller and younger businesses. Heavy tax burdens on labor and consumption repress the market provision of services with close substitutes in the black market and home production. Wage-setting institutions that compress pre-tax wage differentials reinforce this tax effect. International comparisons indicate that market work activity is particularly sensitive to tax rates and wage compression in labor-intensive, service-oriented activities. Many activities that fit this description - such as cooking, cleaning, laundering, landscaping, consumer repair services and a variety of personal services - also offer greater than average scope for self employment, small businesses, start-ups, and family-owned businesses. Hence, in addition to their effects on the level and industry mix of market work activity, these two aspects of the Swedish institutional setup reduced the activity shares of smaller and younger businesses. In addition, Sweden's corporate tax policy, job security mandates, credit market and savings policies and its public sector monopolization of many income-elastic services have also worked against smaller and younger businesses.

\section{Institutional Developments Since 1990 and Related Evidence}

We now turn our focus to Swedish institutional developments since the early 1990s. We consider these developments in the light of both our earlier analyses and Swedish economic performance since the deep crisis of the early 1990s.

\subsection{Wage-Setting Arrangements}

An important new wage-bargaining agreement was introduced in Sweden in 1997 namely, the Agreement on Industrial Development and Wage Formation (Industriavtalet, IA). ${ }^{23}$ It covers about 800,000 workers in the manufacturing sector and 110,000 employees in commerce and transport. It also serves as a model for other agreements covering about 1.3 million workers in the private sector. All told, about 60 percent of Swedish workers are

\footnotetext{
${ }^{23}$ See Elvander (2002) and Djerf et al. (2003) for a more thorough description of the IA and its functioning.
} 
directly covered by the IA or by other agreements modelled on it. Important sectors not covered by the IA include transportation, construction and much of retail trade.

The IA is a further step towards more decentralised and individualised wage-setting, a process that is often said to have started in 1983 when the metal workers' union defected from the centralized regime (Hibbs and Locking 2000). Under the IA, many agreements are reached that make no reference to centrally negotiated pay structures - everything is decided at the local level. Most agreements, however, still incorporate guarantees regarding minimum pay levels. The IA stipulates that trade unions and employers' organizations must assume greater responsibility for wage formation by reaching special collective agreements on cooperation and bargaining procedures. In order to become effective, an agreement must include timetables for negotiations, rules concerning the appointment of impartial mediators and the extent of their powers, and rules concerning the termination of the agreement.

The more fundamental question is whether this new wage-setting regime has also affected bargaining outcomes. After the demise of centralized bargaining in the early 1980s, wage dispersion began to increase among blue- and white-collar workers (Edin and Topel 1997, Hibbs and Locking 2000, and Davis and Henrekson 2005b). As Lundborg (2005) documents, wage dispersion among blue-collar workers levelled off in the mid 1990s, but began to rise even more sharply among white-collar workers in the private sector. Moreover, average real wages began to increase much faster among white-collar workers. From 1995 to 2005 average real wages rose by 43 percent for white-collar workers as compared to 22 percent for bluecollar workers (based on a comprehensive wage measure that includes bonuses, paid overtime and fringe benefits). ${ }^{24}$ Hence, the last ten years saw a considerable widening of the wage gap between white-collar and blue-collar workers and a sharp increase in wage dispersion among white-collar workers (see also Fredriksson and Topel 2006). Lundborg (2005) argues that increased wage dispersion among white-collar workers reflects a greater role for efficiency wage setting.

\subsection{Taxes on Labor and Consumption}

The simple theory of task allocation sketched in Section 3.2 identifies the tax-distorted comparative advantage ratio as a key determinant of market work activity and its composition. Section 3.2 also summarizes evidence regarding the impact of consumption and labor taxes on the extent and industry mix of market work activity. Motivated by our earlier analysis, Figure 8 plots the evolution of the tax-distorted comparative advantage ratio, or tax factor, for three types of Swedish workers. The values in Figure 8 capture mandatory social security contributions, consumption taxes and marginal tax rates on labor income.

Swedish workers faced modest tax factors in the early 1950s of around 2 for executives and lower for others. The tax factors rose steadily after 1952. By the late 1970s, they reached levels near 4 for industrial workers, above 5 for white-collar workers and above 8 for executives. The tax factors declined somewhat in the 1980s, dropped sharply with the tax reform of 1990/91, and crept upwards in recent years as the result of higher tax rates at the local government level. As of 2006, Swedish tax factors stand at 2.54 for industrial workers, 3.44 for white-collar workers and 3.85 for executives. Though well below levels in the 1970s and 1980s, tax factors in this range provide powerful incentives to shift production and employment out of the formal market sector. As a result, large parts of the service sector face

\footnotetext{
${ }^{24}$ Statistics Sweden and the Confederation of Swedish Enterprise (2006).
} 
harsh competition with unpaid work and the black market. These tax effects are amplified by institutions that compress the pre-tax wage distribution, as we explained in Section 3.2.

Figure 8 Tax-Distorted Comparative Advantage Ratios for Three Types of Worker in Sweden, 1952-2006.

\section{Enclosed}

Source: Du Rietz (1994) and new calculations supplied by Du Rietz.

Note: The tax factor for each category is evaluated at mean earnings each year. "Executive" is defined as an individual in the management group (below the CEO) in a private firm. The tax factor includes mandatory social security contributions paid by the employer or the employee, the marginal income tax and indirect taxes on private consumption (all income is assumed to be spent for private consumption purposes). Property taxes are excluded. The tax wedges for executives and average white-collar workers coincide between 1991 and 1998.

Figure 8 does not account for some important tax avoidance strategies. The income tax code in Sweden and many other countries provides significant opportunities for households to reduce effective tax burdens by shifting income to tax-favored sources, by incurring taxdeductible expenses and by engaging in certain portfolio transactions. Prior to Sweden's tax reform in 1990-1991, high-income earners "could exploit a number of asset transactions to escape taxation" (Agell et al. 2004). These transactions included "complex schemes of transforming corporate income into low-taxed capital gains," an unlimited ability to subtract net negative asset income from labor income when calculating taxable income, tax-deductible interest payments, the purchase of tax-preferred assets with borrowed funds, and intra-family debt transactions. Households could also, within limits, invest in untaxed pension funds and tax-favored savings accounts. Agell and Persson (2000) and Agell et al. (2004) present several pieces of evidence that high-income Swedish households used these tax avoidance strategies to a significant extent. For example, "In 1980, when the income tax was highly progressive, [realized capital losses and tax-favored pension savings] allowed the average individual in decile 10 to reduce the average tax on labor income from 52.6 percent to 42.1 percent.”

For our purposes, the theoretical and empirical literature on these asset-based tax avoidance strategies yields some cautionary lessons. First, effective tax factors are undoubtedly smaller than reported in Figure 8. Second, the 1990-1991 Swedish tax reform engineered a smaller reduction in effective tax factors than suggested by Figure 8, or any other examination of statutory tax rates. In line with this conclusion, Malmer and Persson (1994) find that the discrepancy between taxable income and labor income declined substantially in the wake of the 1990-91 tax reform. Similarly, Agell et al. (1998) report that Swedish households initiated a rapid pay down of their debts in the early 1990s. Third, because the tax reform imposed new restrictions on asset-based tax avoidance strategies, it is possible that the reform actually raised effective tax rates for many high-income earners. Hence, without further and careful study, it is unclear whether and how much the tax reforms in 1990/91 stimulated employment, or how much they softened the incentives to shift certain production activities to the underground economy and unpaid household work.

\subsection{Taxation of Business Income}

The substantial tax preference for debt financing described in Section 3.3 presupposed a policy of strictly regulated capital markets. However, the deregulation of domestic capital 
markets in the latter half of the 1980s greatly expanded credit availability even as the tax system remained virtually unchanged and foreign exchange controls continued to limit investment abroad by Swedish households (Jonung 1994; Norrman and McLure 1997). Later, in 1991, the corporate tax rate was cut in half to its current value of 28 percent. $^{25}$ The conversion to a dual income tax system with a 30 percent flat tax rate on capital income in 1991 and the abolition of wealth taxation on unlisted stock in 1992 favored individual equity investments relative to the earlier situation.

In a series of reforms between 1985 and 1994, the distortions in tax wedges across different owners and sources of finance were to a large extent evened out. After 1995, the difference between households and tax-exempt institutions in the marginal tax rates on equities rose once again. See Table 7 (and Table 6 for earlier years).

Table 7 Effective Marginal Tax Rates for Different Combinations of Owners and Sources of Finance, 1991, 1994 and 2005.

\begin{tabular}{lrrr}
\hline & Debt & $\begin{array}{r}\text { New share } \\
\text { issues }\end{array}$ & $\begin{array}{r}\text { Retained } \\
\text { earnings }\end{array}$ \\
\hline 1991 & & & \\
Households & 31.7 & 61.8 & 54.2 \\
Tax exempt institutions & -9.4 & 4.0 & 18.7 \\
Insurance companies & 14.4 & 33.3 & 31.6 \\
& & & \\
1994 & & & \\
Households & $32.0 / 27.0 \dagger$ & $28.3 / 18.3 \dagger$ & $36.5 / 26.5 \dagger$ \\
Tax exempt institutions & -14.9 & 21.8 & 21.8 \\
Insurance companies & 0.7 & 32.3 & 33.8 \\
& & & \\
2005 & & & \\
Households & $27.9 / 22.9 \dagger$ & $58.1 / 48.1 \dagger$ & $42.7 / 32.7 \dagger$ \\
Tax exempt institutions & -1.2 & 23.2 & 23.1 \\
Insurance companies & 18.2 & 44.6 & 42.6 \\
\hline
\end{tabular}

†Excluding wealth tax; the wealth tax on unlisted shares was abolished in 1992. Hence, the higher figure applies only to the securities of listed companies.

Notes: The calculations assume a real pre-tax return of 10 percent, an asset holding period of 10 years, and a realized inflation rate equal to the actual one in the indicated year. The calculations conform to the general framework developed in King and Fullerton (1984).

Source: Calculations provided by Jan Södersten; see Södersten (1993).

When the restrictions on foreign ownership were lifted in a series of steps from 1990 to 1993 (Reiter 2001), attention shifted to the relative treatment of foreign and Swedish owners. The new system represented a significant step towards neutrality among different categories of Swedish owners. However, the tax burden on Swedish individual ownership remains heavier than the tax burden on individual ownership in most other countries (Henrekson and Jakobsson 2005). The more favorable tax situation of foreign owners implies that their pre-tax required rates of return are lower than those of Swedish owners (except for Swedish tax-

\footnotetext{
25 At first it was reduced to 30 percent. See Agell et al. (1998) for a detailed examination of the tax reforms in the early 1990s.
} 
exempt institutions), i.e., foreign owners, ceteris paribus, can pay a higher price for Swedish corporate assets than Swedish (rival) owners (Norbäck et al. 2006). Globalization has also made it easier for large Swedish incumbents to shift their ownership stakes to foreign tax jurisdictions in order to reduce corporate tax burdens and escape personal taxation on ownership (Henrekson and Jakobsson 2005).

Tax loop holes continue to channel individual wealth into institutional equity funds rather than owner-operated businesses. For closely held companies there are particular restrictions on the payment of dividends, the so-called 3:12 rules. These rules were introduced in 1991 to prevent owners of profitable small businesses from saving on taxes by paying themselves dividends taxed at 30 percent rather than wages taxed at the marginal tax rate for labor income. The scope for dividend payments was therefore restricted to a relatively small percentage of the equity capital paid in by owners. The 3:12 rules also raised the capital gains tax on small businesses. Until 2005 it was normally 43 percent for small closely held firms instead of the regular 30 percent, since half of the capital gain was taxed as wage income. Effective from 2006, capital gains from the sale of closely held firms is taxed as wage income on all gains less than SEK 4.4 million. However, the new system also entails some tax relief provisions and is highly complex, which makes it extremely difficult to asses ex ante its overall impact on effective tax rates. ${ }^{26}$

Despite, and in some respects because of, recent changes, there remain a number of provisions in the corporate tax code that benefit large firms and institutional investors relative to smaller, closely held firms. To the extent that it would be efficient for more firms to be managed by individual entrepreneurs, the current tax system creates welfare losses. A priori, industries that benefit from entry by new owner-managed firms are penalized in this tax regime. This stands in stark contrast to U.S. corporate taxation, where dividends in the socalled S-corporations are only taxed at the level of the owner's personal income tax (Cullen and Gordon 2006).

Cullen and Gordon also point out that the asymmetry in the tax treatment of business profits and losses is greater in Sweden than in the United States. ${ }^{27}$ Indeed, the asymmetry actually runs the other way in the United States in some cases. In this regard, they write: "For individuals in the top bracket, risk taking in start-up firms is heavily subsidized in the U.S., but tax penalized in Sweden.” The usual tax asymmetry discourages risk-taking activities even for risk-neutral owners. Since startup activities are often risky, this effect bites harder with respect to new firms than incumbents. It also bites harder for smaller firms insofar as they have more volatile profit streams and fewer opportunities to apply losses in some units to reduce taxes on the gains accruing to other units. For closely held firms, the disincentive to pursue risky activities is even stronger insofar as risk-averse owners have much of their wealth tied up in the firm.

Furthermore, the use of stock options to encourage and reward entrepreneurial behavior among employees is highly penalized by the Swedish tax system, because gains on options are taxed as wage income if the options are tied to employment in the firm. Thus, they are subject both to mandatory social security contributions (33 percent) and the marginal tax rate

\footnotetext{
26 See Lodin (2006) and Andersson et al. (2006).

27 Asymmetry refers to a situation whereby the effective tax rate on business profits is greater than the fraction of business losses shared by the government through the tax system.
} 
on personal income. ${ }^{28}$ In practice, therefore, stock options are less attractive and effective as a tool for rewarding and encouraging entrepreneurial behavior. This is likely to penalize sectors, industries, and positions (key managers and innovators) for which options are an effective response to agency problems.

In order to bridge the gap between founders of firms and external financiers, strategies have differed across countries (Botazzi and Da Rin 2005). It is now widely recognized that venture capital firms can play a crucial role in the development of small entrepreneurial ventures by converting high-risk opportunities to a more acceptable risk level through portfolio diversification, and by adding key competencies that the firm lacks. These goals are achieved by arrangements that align the incentives of the three agents - investors, venture capitalists and entrepreneurs (Zider 1998; Gompers and Lerner 2001). However, the abovedescribed tax schedules apply to this industry as well, which means that a highly competent venture capital industry providing high-powered incentives to investment managers is much harder to develop in Sweden. ${ }^{29}$

In the United States, venture capitalists often buy out the start-up entrepreneur at an early stage in the life-cycle of the firm (Hellman and Puri 2002). While the entrepreneur loses control, he or she often becomes quite wealthy when the venture capitalist and the entrepreneur exit in an IPO (Gompers and Lerner 2001). Venture capitalists, and sometimes entrepreneurs, use the proceeds of IPOs to invest in new entrepreneurial ventures. In contrast, Swedish entrepreneurs often cling to control throughout their entire careers, showing a strong unwillingness to give up control rights to external financiers (Wiklund et al. 2003, Berggren et al. 2000). Greater emphasis on control rather than growth is consistent with the Swedish tax system, and it may be an important factor behind the observation that few Swedish firms founded in recent decades have grown to large size.

\subsection{Savings Incentives and Asset Control}

Sweden's welfare state provisions undercut the main savings motives for most individuals. First, unemployment insurance, income-dependent pensions, sick-leave benefits, and highly subsidized health and care services provided by the government reduce precautionary savings. Second, asset-based means testing in social assistance schemes exacerbates this effect at the lower end of the income and wealth distribution (Hubbard et al. 1995). Third, pay-as-you-go pension systems lower national savings and investment compared to funded systems (Feldstein 1996). In short, Sweden's welfare system reduces national savings through at least three distinct channels. Given the scale of the Swedish welfare state, it is reasonable to infer that the overall negative effect on national savings is quite large.

\footnotetext{
28 This stands in stark contrast to the U.S. situation, where an employee who accepts stock options can defer the tax liability to the time when the stocks are sold rather than when the options are exercised. In the United States, there are typically (i) no tax consequences to the employee upon the grant or the exercise of the option; (ii) the employee is taxed at capital gains rates when the stock acquired upon the exercise of the option is sold after a specified holding period; and (iii) there is no deduction available to the employer. This shifts the tax risk in the options back to the government, and thus accomplishes two things: it increases the potential profit from the stock options and it allows budget-constrained individuals to sell stocks whenever they choose (Misher 1984).

${ }^{29}$ See Henrekson and Rosenberg (2001) for a fuller exposition of this issue.
} 
Not surprisingly, disposable income as a share of gross (before-tax) household income is low in Sweden. ${ }^{30}$ Household saving as a share of disposable income is also low compared to other OECD members. Net household saving, defined as disposable income minus final consumption expenditure, fell from roughly 6 percent of disposable income in the 1960s to 4 percent in the 1970s and 1.1 percent in the 1980s. The OECD average stayed in the 10-12 percent range during this period. ${ }^{31}$ Household savings rates rose sharply in response to the crisis and the tax reform in the early 1990s, partly for the reason discussed in Section 4.2. However, as shown in Figure 9 savings rates came down again in the mid 1990s, and they have averaged only 3 percent since the late 1990s. Household financial savings exclusive of life insurance and pension savings have been consistently and strongly negative since 1997.

Figure 9 Financial Household Saving as Share of Disposable Income in Sweden, 1994-2005 (percent).

\section{Enclosed}

Source: Statistics Sweden (online, November 15, 2006).

Note: Life insurance savings mainly consists of tax-deductible, tax deferred savings. No disbursement from these savings is allowed before age 55. Collective pension savings consist of supplementary pension premiums paid by employers for virtually all tenured employees. Payment of such premiums is treated as a fully tax deductible business cost at the firm level. When pensions are paid out from life insurance and the collective schemes, the beneficiary is subject to income taxes at his then-prevailing marginal tax rate. See Grosskopf, Rabe, and Johansson (1997) for a detailed treatment of the tax-preferred nature of life insurance and pension savings.

In addition, Sweden's system of personal taxation continues to function as a barrier to new business development, especially owner-managed businesses. Here, as well, there are several reinforcing effects. First, high tax rates on wage income make it hard for individuals and families to set aside funds for business start-up capital. Second, high personal tax rates on wealth and capital income undercut the financial rewards to direct business ownership and development. As of 2005, Sweden levies a 30 percent tax rate on nominal current yields (dividends, interest and rents), a 30 percent tax rate on nominal capital gains and a 1.5 percent wealth tax on private real estate holdings, interest-bearing instruments and prime listed stock. Third, these high tax rates encourage reliance on savings schemes that escape capital taxation but, in the process, restrict the owner's control of the assets. As a key case in point, there is unlimited scope for saving in so-called capital pension accounts. Funds paid into such accounts escape wealth, income and capital gains taxation; ${ }^{32}$ but the funds cannot be withdrawn before age 55 and then only over a minimum period of five years. In this way, the tax treatment of financial assets and real property encourages the accumulation of illiquid assets controlled by large financial institutions rather than assets under the direct control of the owner. Personal financial assets with these characteristics cannot be used by the asset holder as working capital in an existing owner-operated business or to start a new owneroperated business.

Low savings, high personal tax rates and restrictions on asset control under the Swedish institutional setup make it very difficult for households to accumulate the type of financial

\footnotetext{
${ }^{30}$ Household disposable income is defined as current receipts of households - direct taxes on households - debt service by households.

31 OECD, Historical Statistics 1960-1980 and 1960-1995.

32 Except for an annual tax on the current value of the assets at a rate corresponding to $15 \%$ of the treasury bond rate (roughly $0.4 \%$ in 2006 ).
} 
resources needed for starting and developing owner-operated businesses. ${ }^{33}$ There are sound reasons to think that disincentives to wealth accumulation and asset control lower the propensity for entrepreneurship. The availability of equity financing is an important factor for both startups and the expansion of existing firms. In general, the riskier the business, the greater is the reliance on equity relative to debt financing. Thus, ceteris paribus, small and newly established firms are more dependent on equity financing than large, well-established firms. Low private asset holdings also exacerbate the inherent problem caused by asymmetric information, because wealth-constrained would-be entrepreneurs are unable to signal forcibly to outside investors by making sizeable equity infusions of their own.

There is also evidence supporting the idea that individual wealth affects the probability of becoming an entrepreneur and the propensity to expand existing businesses. For example, Lindh and Ohlsson (1996) find that the likelihood of starting a business in Sweden increases significantly among those who receive an inheritance or a lottery gain. Holtz-Eakin et al. (1994) find similar evidence for the United States. Lindh and Ohlsson (1998) find that a more unequal wealth distribution covaries positively with the share of self-employed over time. Other studies pointing to the connection between personal assets and the propensity to start a business include Blanchflower and Oswald (1998) and Taylor (2001). Hurst and Lusardi (2004) offer a different view of the empirical relationship between financial resources and the propensity to start a business. Their evidence for the United States points to a less important influence of financial resources. Whether their analysis carries over to a country like Sweden - with much greater impediments to asset accumulation and individual asset control - is an open question.

\subsection{Corporate Governance and Foreign Ownership}

As already noted, before the 1990/91 tax reform the combined effect of taxation on capital gains, wealth, profits and dividends strongly discouraged individuals from owning firms and from wealth accumulation in general. Moreover, the tax system encouraged debt financing, which benefits large capital-intensive firms with closer ties to financial institutions. The expected change in ownership structure actually took place: during the post-war period, the household ownership share of listed stock fell sharply from 75 percent in 1950 to 18 percent in 1990, while the institutional share rose commensurately (Norrman and McLure 1997).

There were also numerous legal impediments to foreign ownership both directly or as shareholders in listed firms (Reiter 2001). However, following the removal of all foreign exchange controls and all barriers to foreign ownership of Swedish firms and real estate in a series of steps between 1989 and 1993, a number of changes ensued. First, the foreign ownership share of listed shares began to increase rapidly. It rose from 7 percent in 1989 when foreign exchange and ownership controls began to be lifted to 40 percent ten years later. ${ }^{34}$ Domestic institutions lowered their share almost as much. The foreign ownership share decreased somewhat again in 2001-2002 following the sharp drop in the valuation of firms in the information technology sector.

Until the late 1980s, foreigners established themselves in Sweden mainly by making greenfield investments. But after ASEA merged with Brown Boveri in 1987 to become a

\footnotetext{
${ }^{33}$ Swedes can use their personal residence as collateral for business loans, which potentially mitigates the problems caused by limited financial resources for some households.

${ }^{34}$ Based on data from Statistics Sweden and OM Stockholm Stock Exchange.
} 
Swiss-based company, many Swedish firms including some very large ones were acquired by foreign owners. The number of employees in wholly foreign-owned companies grew rapidly in Sweden over the last two decades. In 1980, approximately 113,000 Swedes were employed in foreign firms. By 2003, this figure rose to 564,000, and almost one out of four employees in the business sector (23 percent) worked for a foreign firm in 2005 (Strandell 2000 and ITPS 2006). ${ }^{35}$

The combined effect of foreign and Swedish taxation is a favoring of all kinds of foreign ownership relative to Swedish individual ownership. It seems reasonable to conjecture that industries and activities amenable to foreign ownership tend to be dominated by larger business organizations. If so, then the gains from new opportunities for foreign ownership of Swedish firms accrue disproportionately to larger businesses, their owners, and industries and activities that are better suited for larger business organizations. The effect is yet another institutional arrangement that favors larger business organizations relative to smaller ones.

\subsection{Government Production of Income-Elastic Services}

There is substantial scope for private entrepreneurs in Sweden to compete with government production through public procurement programs and voucher systems in schooling, child care, etc. In practice, however, public providers are often insulated from competition with private business. For example, the Swedish Competition Authority (2004) documents that government policies often implicitly favor public producers, because public producers do not bear the full cost of production or because their close ties to government procurement and production departments give them an informational advantage. Another example is the use of short contracts for private suppliers that render necessary investments risky. Dareblom (2005) studies a group of women provided with government support to start their own businesses in welfare services. She finds that, although politicians claimed they looked favorably upon private provision of tax-financed services, they were much less favorable ex post when high-quality suppliers threatened the position of public providers.

Due to the de facto public sector monopolization of production in many income-elastic services, vast areas of the economy remain unexploited as sources of commercial growth. In particular in the health sector, it is easy to imagine how a different organizational mode could provide a basis for the emergence of new high-growth firms. Instead, large-scale production in the manufacturing sector has been seen as a model for central parts of the production of highly income-elastic services such as health care, child care, elderly care and education. This has had a profound effect on private sector growth - from 1960 until the late 1990s all net employment growth in Sweden took place in the local government sector (Rosen 1997).

These publicly produced services are, in many cases, highly suitable for production in private and often also small firms. The political decision to produce these services primarily through a public sector monopoly has largely barred this area from both startup activity and the emergence of high-growth firms. Table 8 summarizes the share of private production for

\footnotetext{
35 The trend is similar in all industrialized countries, but much more pronounced in Sweden. From the mid1990s, inward FDIs are very large in Sweden both in an absolute sense and compared to other countries. This was particularly pronounced in the latter half of the 1990s. On average, they corresponded to 55 percent of total gross investment in 1995-99. This figure may be compared to a corresponding level of 31 percent in Ireland, the country which is usually mentioned in this context (UNCTAD, World Investment Report and OECD, Employment Outlook).
} 
the major services that are fully or primarily tax-financed. The private production share is very low in activities like child care, care of the elderly and after-school care, despite the fact that these activities are highly amenable to private, small-firm production.

Table 8 Private Sector Production Share for Major Services that are Primarily Publicly Funded, 1996, 2000 and 2005 (percent).

\begin{tabular}{lrrr}
\hline Service & 1996 & 2000 & 2005 \\
\hline Institutional child care (pre-school) & 12.5 & 11.8 & 16.7 \\
Child care in the home (of the & 2.2 & 8.6 & 12.0 \\
professional) & & & \\
After-school care & 4.5 & - & 9.2 \\
Compulsory schooling & 2.4 & 3.9 & 7.4 \\
High school & 1.9 & 4.4 & 13.4 \\
Care of the elderly at nursing homes & 8.3 & 10.0 & 13.2 \\
Care of the elderly in special apartments & 5.1 & 11.0 & \\
Care of the elderly in their own home & 2.6 & 7 & 9.7 \\
Hospital care & 4.3 & - & $7.3 *$ \\
Medical consultations & 28 & - & 28.7 \\
Share of doctors privately employed & 10 & 7.3 & $7.0^{*}$ \\
Psychiatric wards & 24 & - & 5.9 \\
Children's dental care & 5 & - & 9.8 \\
\hline
\end{tabular}

* 2004.

Source: Werenfels Röttorp (1998) for 1996; Jordahl (2002) for 2000; Socialstyrelsen (2006) for care of the elderly in 2005, The Swedish National Agency for Education (www.skolverket.se/content/1/c4/62/39/) for all schooling measures in 2005 and Jordahl (2006) for health and dental care in 2006.

\subsection{Labor Market Reforms}

Some deregulatory measures in the labor market have been taken. In 1997 a new type of employment contract was allowed, so-called prearranged temporary employment, which gives every firm an unconditional right to employ up to five persons for a maximum of one year. Another 1997 change made it possible to sign local collective agreements that replace the regulations in the law. This makes it possible, through local agreements, to annul tenure-based orders of priority in case of dismissal, to annul the right to reemployment for dismissed workers, and to extend the duration of temporary employment beyond 12 months. In practice, this benefits larger firms that have enough clout to strike bargains with the unions, and it also makes it necessary to be unionized; otherwise, the law applies by default. In 2001 firms with no more than 10 employees were allowed to exempt two employees from the "last-in - firstout" rule in case of redundancies. ${ }^{36}$ A law passed in 1993 paved the way for an expansion of temporary work businesses and staffing services. These firms expanded at a rapid rate and now employ roughly 1.3 percent of the workforce in the private sector.

\footnotetext{
${ }^{36}$ Lindbeck, Palme and Persson (2006) find that after the 2001 change relative absenteeism in small firms fell, and the propensity to employ people with much previous sickness leave increased in firms with ten or fewer employees.
} 
On the other side of the ledger, some measures have been taken or proposed that entail increased obligations for firms or restrict their leeway in contracting and hiring. The responsibility of employers for the rehabilitation of employees on long-term sick leave has been extended, and employers are obligated to pay part of the sick leave compensation (15 percent) indefinitely. ${ }^{37}$ The latter obligation has been abolished from January 2007 by the new non-socialist government that took office in October 2006.

\section{Concluding Remarks}

Since a deep economic contraction in the early 1990s, Sweden has enjoyed strong output growth relative to the 1970s and 80s and relative to contemporaneous experience in much of the OECD and EU. However, relatively rapid output growth failed to produce much recovery in employment or market work hours. At this writing, thirteen years after the trough in 1993, hours worked per person of working age remain roughly 10 percent below their peak in 1990 . International comparisons indicate that Swedes spend considerably less time in market work activity than Americans and the average for European countries.

This state of affairs is largely consistent with our earlier analysis and what could be expected from the modest changes in Sweden's institutional setup in recent decades. In particular, our evidence and analysis indicate that the Swedish institutional setup strongly depresses market work activity, particularly in services "on the margin” between market and non-market provision. There have been institutional improvements in the 1980s and 1990s, but we do not detect a strong and consistent move toward a more work friendly set of institutions and policies. In our judgment, the institutional setup in Sweden has basically moved sideways in terms of promoting work activity, providing fertile ground for younger and smaller businesses and facilitating a more efficient deployment of factor inputs. In the same period, it is fair to say that increased global integration of markets and national economies has intensified the competitive pressures facing many Swedish firms and workers.

One possible reaction to our evidence and analysis is a shrug of complacency. If Swedes choose to enjoy the fruits of economic progress in the form of more leisurely lifestyles and a more robust social safety net, that is a perfectly reasonable, even sensible, path to follow. We think this view is much too sanguine, and for several reasons. First, the dramatic drop in Swedish work activity in the early 1990s coincided with a sharp contraction in output and real incomes. Moreover, low work time is not "taken" by individuals with high income; rather, it mainly reflects persons of relatively modest means who work little or not at all (Björklund and Freeman, 2006). These time-series and cross-sectional patterns do not fit a story of rising real incomes used to purchase additional leisure. As a related point, Swedish institutions prevent many persons from finding a preferred tradeoff between work and leisure. In particular, Ljungqvist and Sargent (2006) explain how employment security provisions coupled with unemployment benefits tied to past earnings impede the return to work after job loss. The effect is to raise structural unemployment in the wake of major macroeconomic shocks or increased levels of microeconomic uncertainty.

\footnotetext{
37 The government that lost the election in September 2006 proposed legislation that would give employees on part-time contracts a unilateral right to demand full-time work, make it harder for employers to circumvent tenure rules through temporary contracts, and tighten rules against dismissal of persons on parental leave.
} 
Second, the inviting leap from low market work hours to high leisure is a treacherous one. Data from time-use surveys indicate that working-age Swedes devote nearly as much time to work as Americans, once domestic household work is factored into the comparison. Workingage Swedes actually enjoy less leisure than their American counterparts according to our comparison of recent time-use surveys. Drawing on Eurostat time-use data, Ragan (2005) reports that people tend to spend more time in household production activities in countries with low market work hours. The time-use evidence squares neatly with the evidence that Sweden and other high-tax countries have comparatively small output and employment shares in sectors that produce time-saving goods and services.

Third, recent international studies find evidence of a sizable elasticity of aggregate work hours with respect to the combined tax rate on labor income and consumption expenditures. See Davis and Henrekson (2005a), Dew-Becker and Gordon (2006) and Rogerson (2006). Our own work based on cross-country variation in a small sample of rich countries in 1995 yields an estimated hours elasticity of -0.55 . Dew-Becker and Gordon (2006) estimate an elasticity of -0.4 based on time-series variation from 1960 to 2004 in a sample of rich countries. We interpret these estimated elasticity values as reflecting the combined effects of high tax rates on labor supply and demand plus the effects of tax-funded welfare and social insurance programs on labor supply incentives. Tax and spending effects of this magnitude are likely to generate sizable welfare losses in a country with a public sector as large as Sweden’s (Aronsson and Walker, 2006).

Fourth, a narrow focus on the elasticity of hours worked with respect to the tax rate understates the welfare costs of the Swedish institutional setup in several ways. As we explain in Section 3.2, the distortionary effects of high tax rates on labor and consumption are amplified by Swedish institutions that compress pre-tax wage differentials. As recently stressed by Feldstein (2006), the (static) welfare costs of taxation are generated by the elasticity of taxable income with respect to tax rates, and taxable income is probably more responsive than hours alone. In addition, there are dynamic efficiency losses associated with occupational choice, schooling attainment, and other decisions that affect human capital. Finally, there are other distortions that we have attributed to the Swedish institutional setup namely, the misallocation of capital across sectors and the many impediments to smaller and younger businesses. 


\section{References}

Acemoglu, Daron, Simon Johnson and James A. Robinson (2005), "Institutions as the Fundamental Cause of Long-Run Growth.” In Philippe Aghion and Steve Durlauf, eds., Handbook of Economic Growth. Amsterdam: North-Holland.

Agell, Jonas, Peter Englund and Jan Södersten (1998), Incentives and Redistribution in the Welfare State - The Swedish Tax Reform. London: Macmillan.

Agell, Jonas and Mats Persson (2000), “Tax Arbitrage and Labor Supply.” Journal of Public Economics 78(1), 3-24.

Agell, Jonas, Mats Persson and Hans Sacklén (2004), “The Effects of Tax Reform on Labor Supply, Tax Revenue and Welfare when Tax Avoidance Matters.” European Journal of Political Economy 20(4), 963-982.

Aguiar, Mark and Erik Hurst (2006), "Measuring Trends in Leisure: The Allocation of Time over Five Decades.” working paper, University of Chicago.

Albaeck, Karsten, Mahmood Arai, Rita Asplund, Erling Barth and Erik Strøjer Madsen (1998), “Measuring Wage Effects of Plant Size.” Labour Economics 5(4), 425-448.

Alesina, Alberto, Edward L. Glaeser and Bruce Sacerdote (2005), "Work and Leisure in the United States and Europe: Why so Different?” NBER Macroeconomics Annual 2005, 164.

Andersson, Krister, Johan Fall and Ingrid Melbi (2006), ”Kommentar till Sven-Olof Lodins artikel om de nya 3:12-reglerna.” Skattenytt, 5, 278.

Aronsson, Thomas and James R. Walker (2006) "Labor Supply, Tax Base and Public Policy in Sweden.” Manuscript, August.

Baumol, William J. (1990), “Entrepreneurship: Productive, Unproductive and Destructive.” Journal of Political Economy 98(5), 893-921.

Berggren, Björn, Göran Lindström och Chriser Olofsson (2000), "Control Aversion and the Search for External Financing.” Small Business Economics 15(3), 233-242.

Björklund, Anders and Richard B. Freeman (2006) "Searching for Optimal Inequality/Incentives: Sweden’s Effort to Reach Economic Valhalla.” Manuscript, September.

Blanchflower, David G. and Andrew J. Oswald (1998), “What Makes an Entrepreneur?” Journal of Labor Economics 16(1), 26-60.

Blau, Francine D. and Lawrence M. Kahn (1999), "Institutions and Laws in the Labor Market.” In Orley Ashenfelter and David Card, eds., Handbook of Labor Economics, Volume 3. Amsterdam: North-Holland.

Bottazzi, Laura and Marco Da Rin (2005), Financing Entrepreneurial Firms in Europe: Facts, Issues, and Research Agenda. CESifo Seminar Series, Vol. 9. Cambridge and London: MIT Press.

Confederation of Swedish Enterprise (2006), Fakta om löner och arbetstider 2006. Stockholm: Svenskt Näringsliv.

Cressy, Robert and Olofsson, Christer (1997), ”The Financial Constraints for Swedish SMEs: Survey and Research Agenda.” Small Business Economics 9(2), 179-194. 
Cullen, Julie Berry and Roger H. Gordon (2006), ”How Do Taxes Affect Entrepreneurial Activity?: A Comparison of U.S. and Swedish Law.” Mimeo. UC San Diego.

Dareblom, Jeanette (2005), Prat, politik och praktik - Om individers möten med strukturer i en kommunal satsning på kvinnors företagande. Ph D Dissertation. Center for Business Creation. Stockholm School of Economics.

Davis, Steven J. and John Haltiwanger (1996), "Employer Size and the Wage Structure in U.S. Manufacturing.” Annales d'Économie et de Statistique 41/42, 323-367.

Davis, Steven J., John Haltiwanger, Ron Jarmin and Javier Miranda (2006), "Volatility and Dispersion in Business Growth Rates: Publicly Traded versus Privately Held Firms.” NBER Working Paper No. 12354. Forthcoming in the NBER Macroeconomics Annual.

Davis, Steven J., John Haltiwanger and Scott Schuh (1996), Job Creation and Destruction. Cambridge, MA: MIT Press.

Davis, Steven J. and Magnus Henrekson (1997), ”Industrial Policy, Employer Size and Economic Performance in Sweden.” In Richard B. Freeman, Robert Topel and Birgitta Swedenborg, eds., The Welfare State in Transition. Chicago: University of Chicago Press.

Davis, Steven J. and Magnus Henrekson (1999), "Explaining National Differences in the Size and Industry Structure of Employment.” Small Business Economics 12(1), 59-83.

Davis, Steven J. and Magnus Henrekson (2005a), “Tax Effects on Work Activity, Industry Mix and Shadow Economy Size: Evidence from Rich-Country Comparisons.” In Ramón Gómez-Salvador et al., eds., Labour Supply and the Incentives to Work in Europe. Cheltenham, UK: Edward Elgar.

Davis, Steven J. and Magnus Henrekson. (2005b), "Wage-Setting Institutions as Industrial Policy.” Labour Economics 12(3)3, 345-377.

Davis, Steven J. and Magnus Henrekson (2006), “Företagandets villkor, tillväxten och sysselsättningen i 90-talskrisens kölvatten?” In Richard B. Freeman, Birgitta Swedenborg and Robert Topel, eds., Att reformera välfärdsstaten. NBER Rapporten II. Stockholm: SNS Förlag.

Davis, Steven J. and Luis Rivera-Batiz (2006), “The Climate for Business Development and Employment Growht in Puerto Rico.” In Susan M. Collins, Barry Bosworth and Miguel A. Soto-Class, eds., The Economy of Puerto Rico: Restoring Growth. Washington DC: Brookings Institution Press and Center for the New Economy.

Devereux, Michael P. and Rachel Griffith (2003), "Evaluating Tax Policy for Location Decisions.” International Tax and Public Finance 10(2), 127-126.

Dew-Becker, Ian and Robert J. Gordon (2006), "The Slowdown in European Productivity Growth: A Tale of Tigers, Tortoises and Textbook Labor Economics.” Working Paper, July.

Djerf, Olle et al. (2003), “Köpkraft och konkurrenskraft - tredje avtalsrörelsen med Industriavtalet.” Ekonomisk Debatt 31(8), 16-26.

Du Rietz, Gunnar (1994), Välfärdsstatens finansiering. Stockholm: City University Press.

Edling, Jan (2005), Alla behövs. Blott arbetsmarknadspolitik skapar inga nya jobb. Stockholm. 
Elvander, Nils (2002), “The New Swedish Regime for Collective Bargaining and Conflict Resolution: A Comparative Perspective.” European Journal of Industrial Relations 8(2), 197-216.

Feldstein, Martin (1996), ”The Missing Piece in Policy Analysis: Social Security Reform.” American Economic Review 86(2), 1-14.

Feldstein, Martin (2006), “The Effect of Taxes on Efficiency and Growth.” NBER Working Paper No. 12201.

Fredriksson, Peter and Robert Topel (2006), "Wage Determination and Employment in Sweden since the Early 1999s - Wage Formation in a New Setting.” Manuscript, September.

Freeman, Richard B. (1995), “The Large Welfare State as a System.” American Economic Review 85(2), 16-21.

Freeman, Richard B., Robert Topel and Birgitta Swedenborg, eds. (1997), The Welfare State in Transition: Reforming the Swedish Model. Chicago: University of Chicago Press.

Fukao, Mitsuhiro and Masaharu Hanazaki (1987), "Internationalization of Financial Markets and the Allocation of Capital.” OECD Economic Studies, No. 8, 35-92.

Gompers, Paul A. and Josh Lerner (2001), The Money of Invention: How Venture Capital Creates New Wealth. Cambridge, MA: Harvard University Press.

Grosskopf, Göran, Gunnar Rabe, and Gunnar Johansson (1997), Det svenska skattesystemet. Stockholm: Norstedts Juridik

Håkansson, Christina and Assar Lindbeck (2005), “Korpi vilseleder igen. Replik.” Ekonomisk Debatt 33(1), 58-65.

Hart, Oliver, Andrei Shleifer and Robert W. Vishny (1997), ”The Proper Scope of Government: Theory and an Application to Prisons." Quarterly Journal of Economics 112(4), 1127-1161.

Hellmann, Thomas and Manju Puri (2002), "Venture Capital and the Professionalization of Start-Up Firms: Empirical Evidence.” Journal of Finance 57(1), 169-197.

Henrekson, Magnus (2001), "Swedish Economic Growth: A Favorable View of Reform.” Challenge 44(4), 38-58.

Henrekson, Magnus and Ulf Jakobsson (2003), “Ownership Policy and Ownership Structure in Postwar Sweden - Convergence towards the Anglo-Saxon Model?” New Political Economy 8(1), 73-102.

Henrekson, Magnus and Ulf Jakobsson (2005), “The Swedish Model of Corporate Ownership and Control in Transition.” In Harry Huizinga and Lars Jonung, eds., Who Will Own Europe? The Internationalisation of Asset Ownership in Europe. Cambridge: Cambridge University Press.

Henrekson, Magnus and Dan Johansson (1999), "Institutional Effects on the Evolution of the Size Distribution of Firms.” Small Business Economics 12(1), 11-23.

Hibbs, Douglas A. and Håkan Locking (2000), "Wage Dispersion and Productive Efficiency: Evidence for Sweden.” Journal of Labor Economics 18(4), 755-782. 
Holtz-Eakin, Douglas, David Joulfaian and Harvey S. Rosen (1994), “Sticking It out: Entrepreneurial Survival and Liquidity Constraints.” Journal of Political Economy, 102(1), 53-75.

Hubbard, R. Glenn, Jonathan Skinner and Stephen P. Zeldes (1995), ”Precautionary Savings and Social Insurance.” Journal of Political Economy 103(2), 360-399.

Hurst, Erik and Anna Lusardi (2004), ”Liquidity Constraints, Household Wealth and Entrepreneurship.” Journal of Political Economy 112(2), 319-347.

Industriförbundet (1995), Det ekonomiska läget - Att återvinna välståndet. Stockholm.

ITPS (2006), “Utlandsägda företag 2005.” S2006:006. Stockholm: Swedish Institute for Growth Policy Studies (ITPS).

Jonung, Lars (1994), ”The Rise and Fall of Credit Controls: The Case of Sweden, 1939-89.” In Michael D. Bordo and Forrest Capie, eds., Monetary Regimes in Transition. Cambridge: Cambridge University Press.

Jordahl, Henrik (2002), Vad har hänt med de enskilda alternativen? Stockholm: Reforminstitutet.

Jordahl, Henrik (2006), ”Konkurrensutsättning av offentlig verksamhet - Hur stor är effektiviseringspotentialen?” Policy Paper No. 8, Research Institute of Industrial Economics, Stockholm.

Juster, Thomas and Frank P. Stafford (1991), “The Allocation of Time: Empirical Findings, Behavioral Models, and Problems of Measurement.” Journal of Economic Literature 29(2), 471-522.

King, Mervyn A. and Don Fullerton (1984), The Taxation of Income from Capital: A Comparative Study of the United States, the United Kingdom, Sweden and West Germany. Chicago: The University of Chicago Press.

Lallemand, Thierry, Robert Plasmand and Francois Rycx (2005), “The Establishment-Size Wage Premium: Evidence from European Countries.” IZA Discussion Paper No. 1569.

Lallemand, Thierry and Francois Rycx (2005), "Establishment Size and the Dispersion of Wages: Evidence from European Countries.” IZA Discussion Paper No. 1778.

Lindbeck, Assar (1982), "Tax Effects versus Budget Effects on Labor Supply.” Economic Inquiry 20(3), 473-489.

Lindbeck, Assar (1997), “The Swedish Experiment.” Journal of Economic Literature 35(3), 1273-1319.

Lindbeck, Assar, Mårten Palme and Mats Persson (2006), “Job Security and Work Absence: Evidence from a Natural Experiment.” Working Paper No. 660, Research Institute of Industrial Economics, Stockholm.

Lodin, Sven-Olof (2006), “3:12-reglerna och företagsförsäljningar.” Skattenytt, 5, 240-249.

Lundborg, Per (2005), "Individual Wage Setting, Efficiency Wages and Productivity in Sweden.” FIEF Working Paper No. 205, Stockholm.

Ljungqvist, Lars and Thomas J. Sargent (2006), "How Sweden's Unemployment Became More Like Europe's.” Manuscript, August. 
Malmer, Håkan and Annika Persson (1994), "Skattereformens effekter på skattesystemets driftskostnader, skatteplanering och skattefusk" (The effects of the tax reform on compliance costs, tax planning, and tax fraud). In Håkan Malmer, Annika Persson, and Åke Tengblad, eds., Århundradets skattereform. Stockholm: Fritzes.

Misher, Norman (1984), "Tax Consequences of Exercising An Incentive Stock Option with Stock of the Granting Corporation.” The Tax Executive, July, 357-363.

National Audit Office (1997), Svart arbete. RRV 1997:59. Stockholm: Riksrevisionsverket.

Norbäck, Per-Johan, Lars Persson and Jonas Vlachos (2006), "Cross-Border Acquisitions and Corporate Taxes: Efficiency and Tax Revenues.” Working Paper No. 663, Research Institute of Industrial Economics, Stockholm.

Norrman, Erik and Charles E. McLure (1997), ”Tax Policy in Sweden.” In Richard B. Freeman, Robert Topel and Birgitta Swedenborg, eds., The Welfare State in Transition. Chicago: University of Chicago Press.

North, Douglass C. and Barry R. Weingast (1989), “Constitutions and Commitment: Evolution of Institutions Governing Public Choice in Seventeenth Century England.” Journal of Economic History 49(4), 803-832.

NUTEK (1994), Småföretagen - Sveriges framtid? B 1994:4. Stockholm: NUTEK Företag.

OECD (2005), OECD Economic Surveys: Sweden. Paris.

Oi, Walter and Todd L. Idson (1999), “Firm Size and Wages.” In Orley Ashenfelter and David Card, eds., Handbook of Labor Economics, Volume 3. Amsterdam: North-Holland.

Olovsson, Conny (2004), “Why Do Europeans Work so Little?” Seminar Paper No. 727, Institute of International Economic Studies, Stockholm University.

Palda, Filip (1998), "Evasive Ability and the Efficiency Cost of the Underground Economy.” Canadian Journal of Economics 31(5), 1118-1138.

Pontusson, Jonas (1992), The Limits of Social Democracy. Investment Politics in Sweden. Ithaca: Cornell University Press

Prescott, Edward (2004), "Why Do Americans Work So Much More than Europeans?” Quarterly Review of the Federal Reserve Bank of Minneapolis, July, 2-13.

Ragan, Kelly S. (2005), “Taxes, Transfers and Time Use: Fiscal Policy in a Household Production Model.” Mimeo. University of Chicago.

Reiter, Joakim (2003), "Changing the Microfoundations of Corporatism: The Impact of Financial Globalisation on Swedish Corporate Ownership?” New Political Economy 8(1), 103-126..

Reiter, Joakim (2003), "Changing the Microfoundations of Corporatism: The Impact of Financial Globalisation on Swedish Corporate Ownership?” New Political Economy 8(1), 103-126.

Rodrik, Dani, Arvind Subramanian, and Franceso Trebbi (2004). "Institutions Rule: The Primacy of Institutions over Geography and Integration in Economic Development.” Journal of Economic Growth 9(2), 131-165.

Rogerson, Richard (2006), “Understanding Differences in Hours Worked.” Review of Economic Dynamics 9(3), 365-409. 
Rosen, Sherwin (1997), "Public Employment and the Welfare State in Sweden.” In Freeman, Richard B., Robert Topel and Birgitta Swedenborg, eds., The Welfare State in Transition: Reforming the Swedish Model. Chicago: The University of Chicago Press.

Schneider, Friedrich and Dominik H. Enste (2002), The Shadow Economy: An International Survey. Cambridge: Cambridge University Press.

Socialstyrelsen (2006), ”Äldre - vård och omsorg år 2005”. Statistik Socialtjänst 2006:3. Stockholm: Socialstyrelsen.

Södersten, Jan (1984), ’Sweden.” In Mervyn A. King and Don Fullerton, eds., The Taxation of Income from Capital: An International Comparison. Washington, D.C.: Brookings.

Södersten, Jan (1993), ”Sweden.” In Dale W. Jorgenson and Robert Landau, eds., Tax Reform and the Cost of Capital: An International Comparison. Washington D.C.: Brookings.

SOU 1982:52, En effektivare kreditpolitik. Betänkande av kreditpolitiska utredningen. Stockholm: Allmänna Förlaget.

SOU 2002:113, Tullverkets brottsbekämpning, Integritet-Effektivitet. Stockholm: Ministry of Finance.

Strand, Jon (2005), “Tax Distortions, Household Production, and Black-Market Work.” European Journal of Political Economy 21(4), 851-871.

Strandell, Ann-Christine (2000), ”Utlandsägda företag.” In Svenskt näringsliv och näringspolitik 2000. Stockholm: NUTEK Förlag.

Svensson, Roger (2006), “Innovation Performance and Government Financing.” Working Paper No. 664, Research Institute of Industrial Economics, Stockholm.

Swedish Competition Authority (2004), Myndigheter och marknader - tydligare gräns mellan offentligt och privat. Rapport 2004:4. Stockholm: Konkurrensverket.

Swedish National Tax Board (2006), Svartjobb och svartköp i Sverige. Rapport 2006:4. Stockholm: Skatteverket.

Taylor, Mark P. (2001), "Self-Employment and Windfall Gains in Britain: Evidence from Panel Data.” Economica 68(272), 539-565.

Teulings, Coen and Joop Hartog (1998), Corporatism or Competition? Labour Contracts, Institutions and Wages in International Comparison. Cambridge: Cambridge University Press.

Werenfels Röttorp, Monica (1998), "Den offentliga sektorns förnyelse - vad har hänt under de senaste 15 åren?” In Håkan Lundgren et al., På svag is. Stockholm Timbro.

Wiklund, Johan, Per Davidsson och Frédéric Delmar (2002), ”What Do They Think and Feel about Growth? An Expectancy-Value Approach to Small Business Managers' Attitudes Toward Growth.” Entrepreneurship Theory and Practice 27(3), 247-270. 
Figure 1. PPP-Adjusted GDP per Capita in Sweden as Percent of OECD Average, Penn World Tables (1950-92) and OECD Statistics (1970-2004), OECD-23 = 100

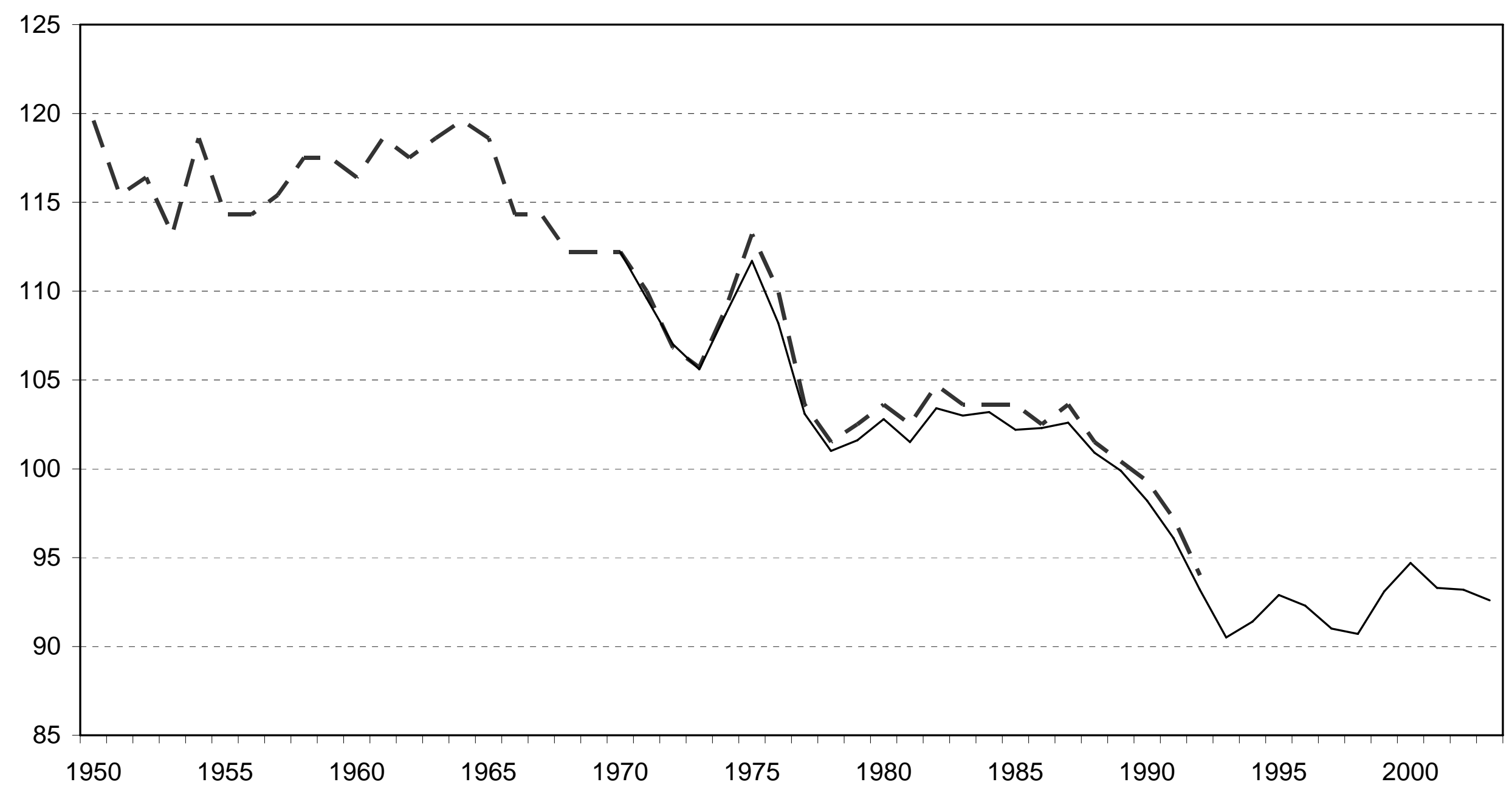


Figure 2. Cumulative Employment and Population Change in Sweden, 1950 - 2004

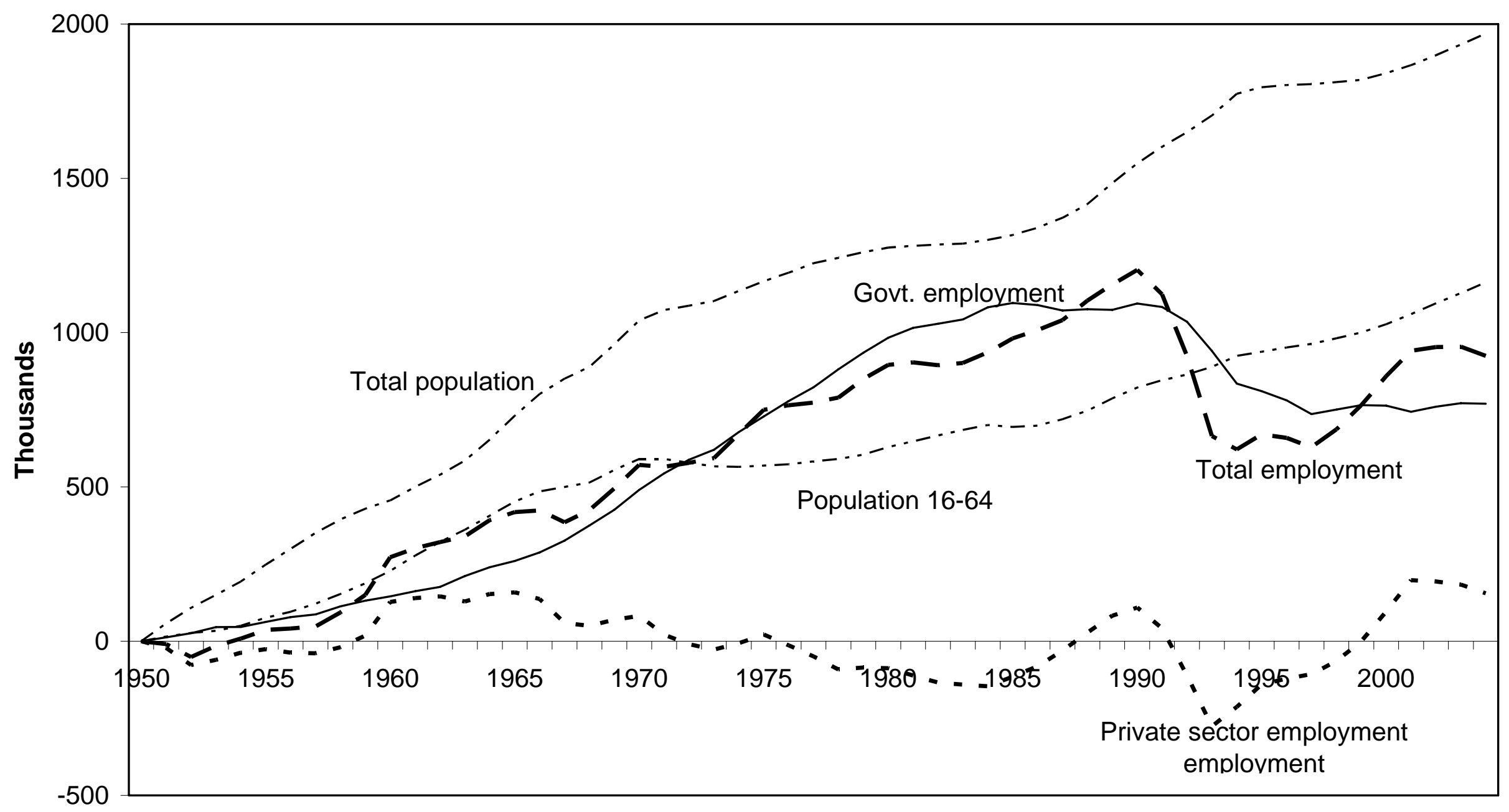




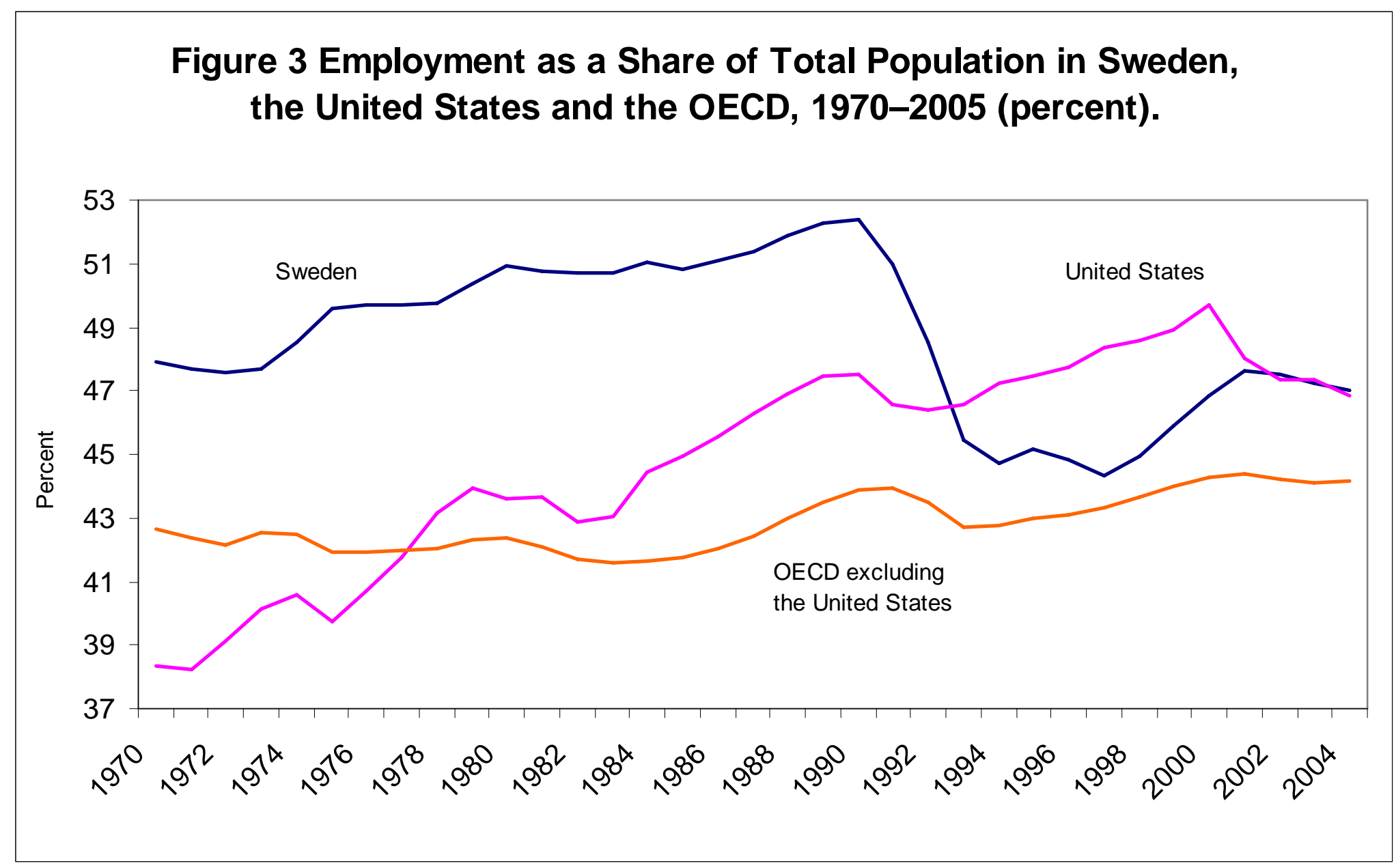


Figure 4. Average annual hours worked, 1990-2004, Sweden

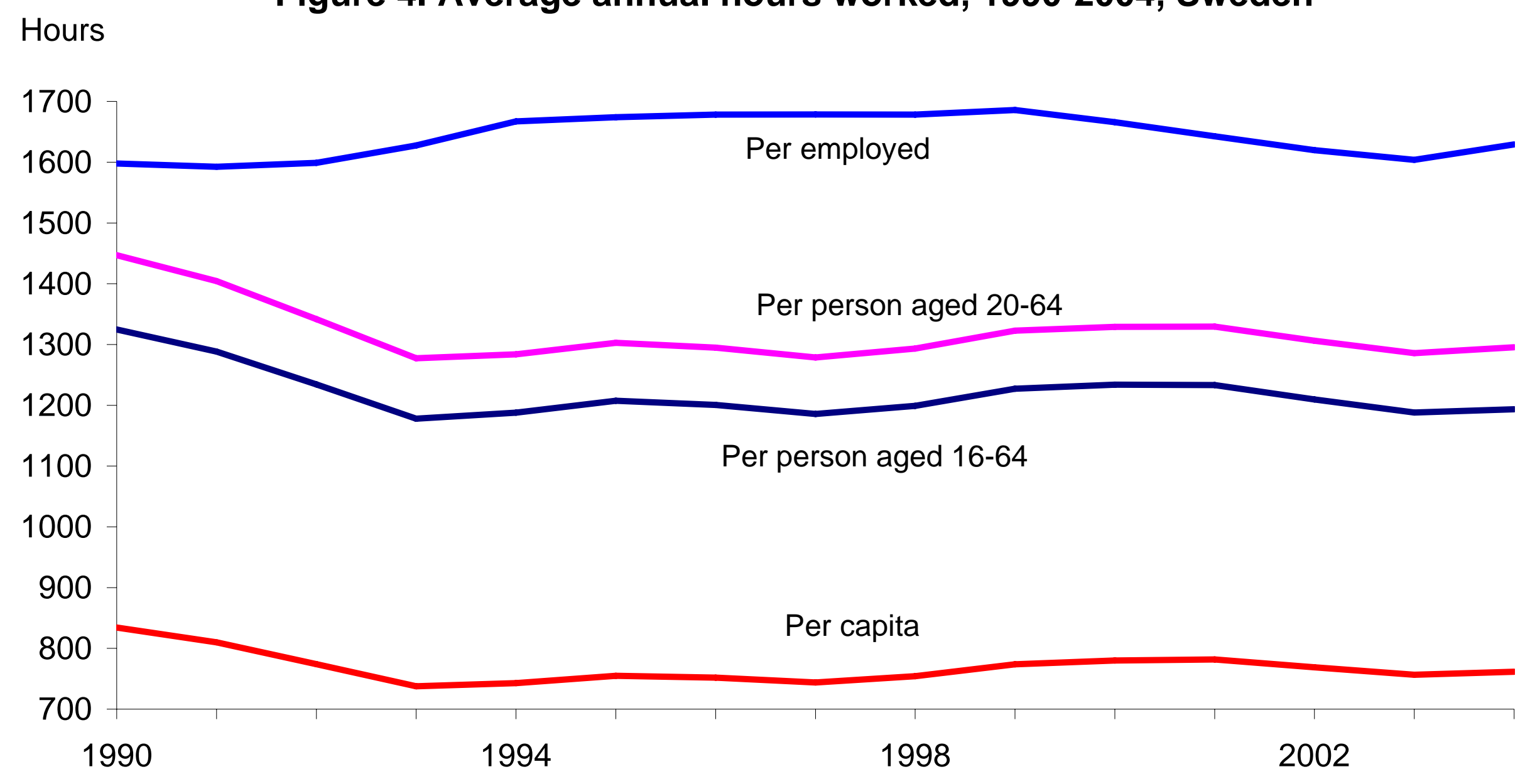




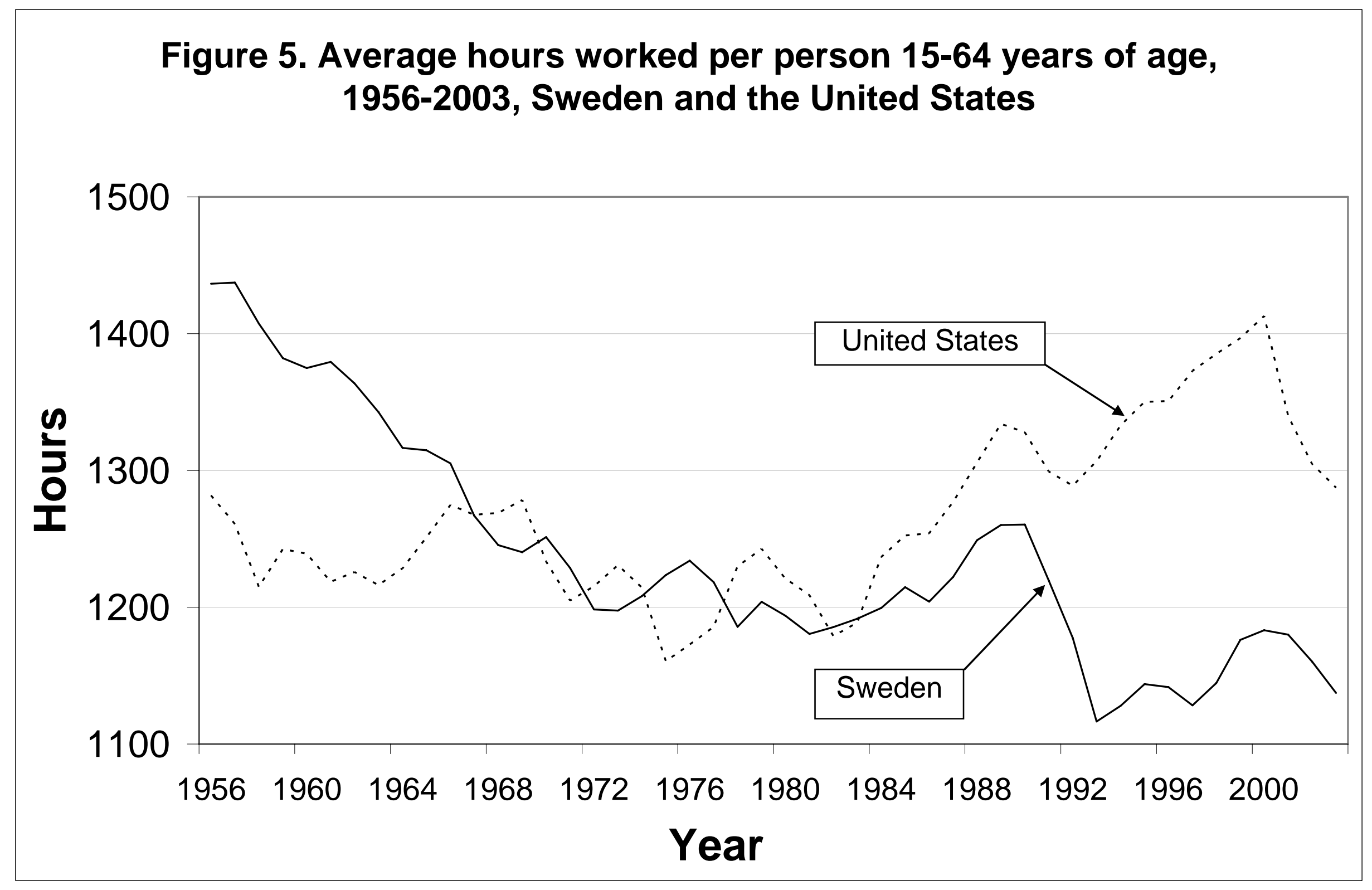




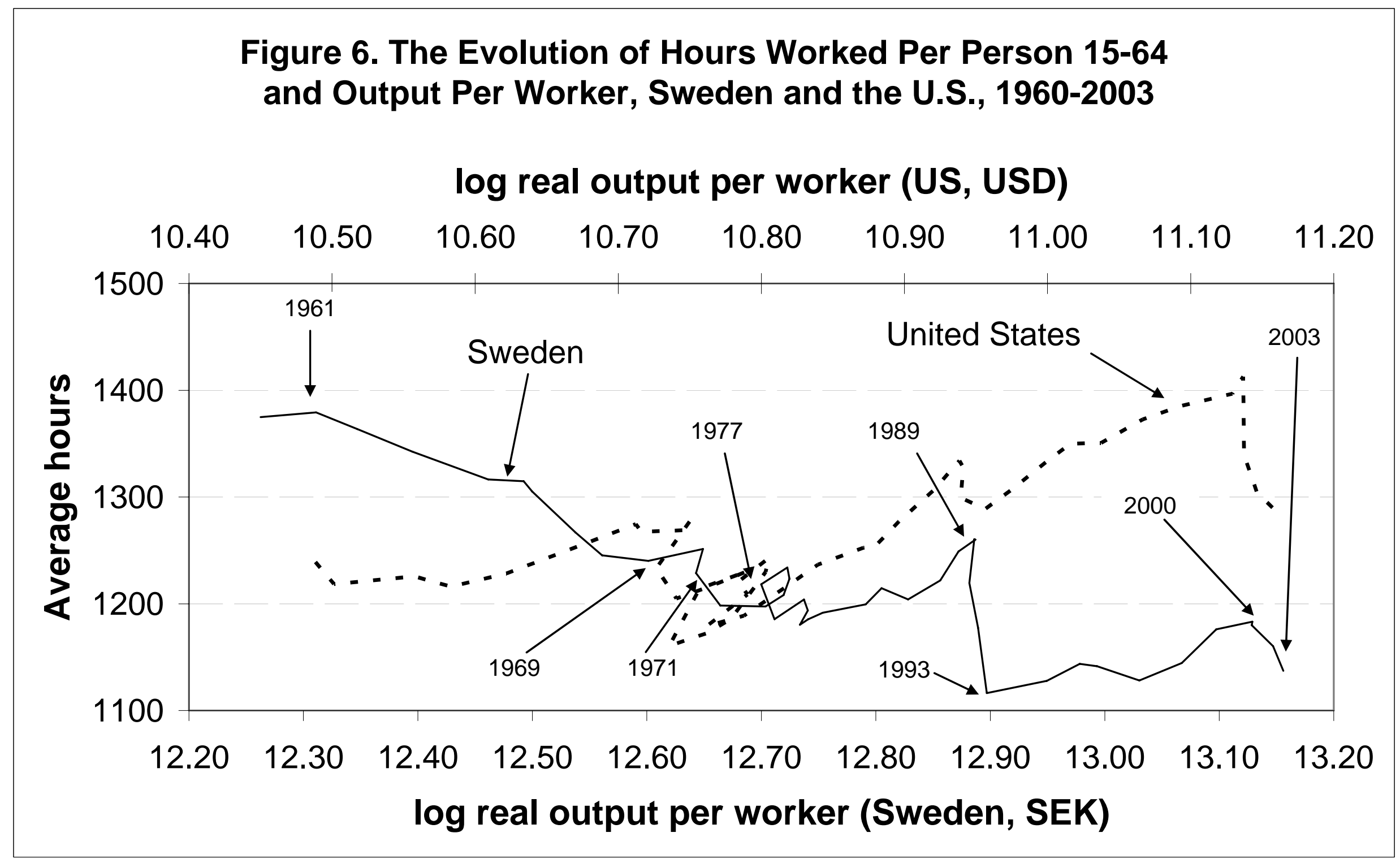


Figure 7(a). Percent of Total Employment in Selected Services and Tax-Distorted Comparative Advantage

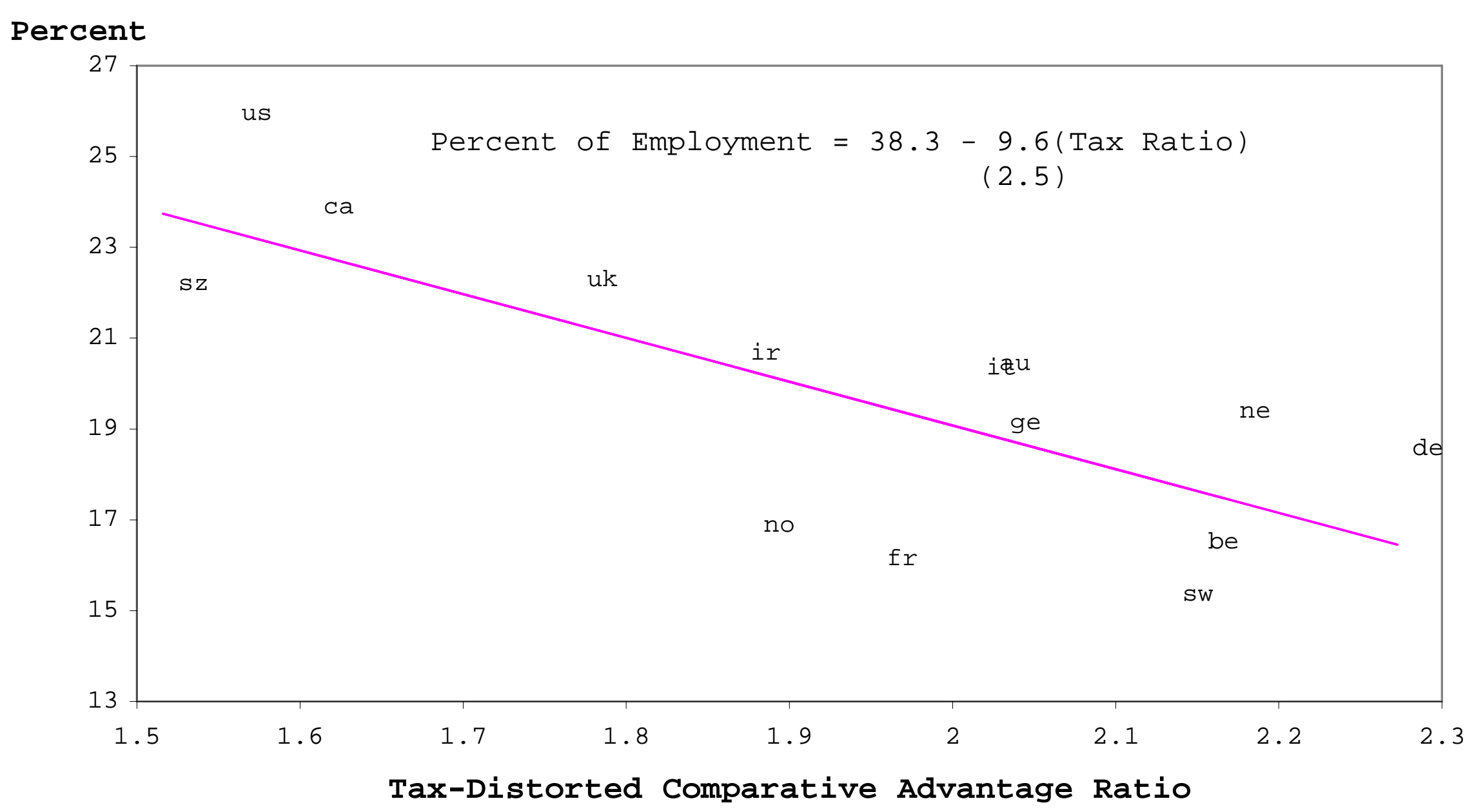


Figure 7(b). Percent of Value Added in Selected Services and TaxDistorted Comparative Advantage

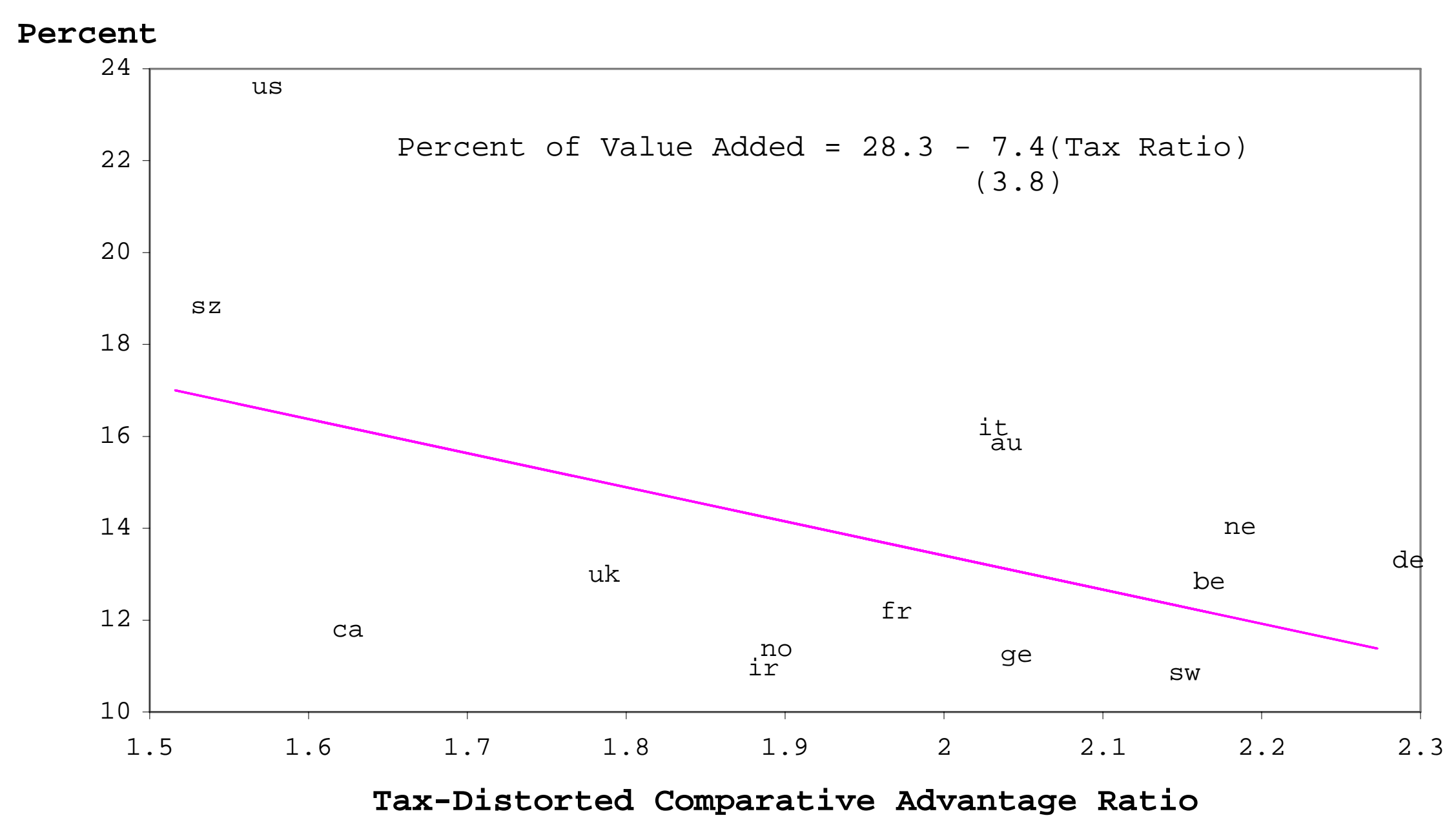


Figure 8 Tax-Distorted Comparative Advantage Ratios for Industrial Workers, White-Collar Workers and Executives in Sweden, 1952-2006

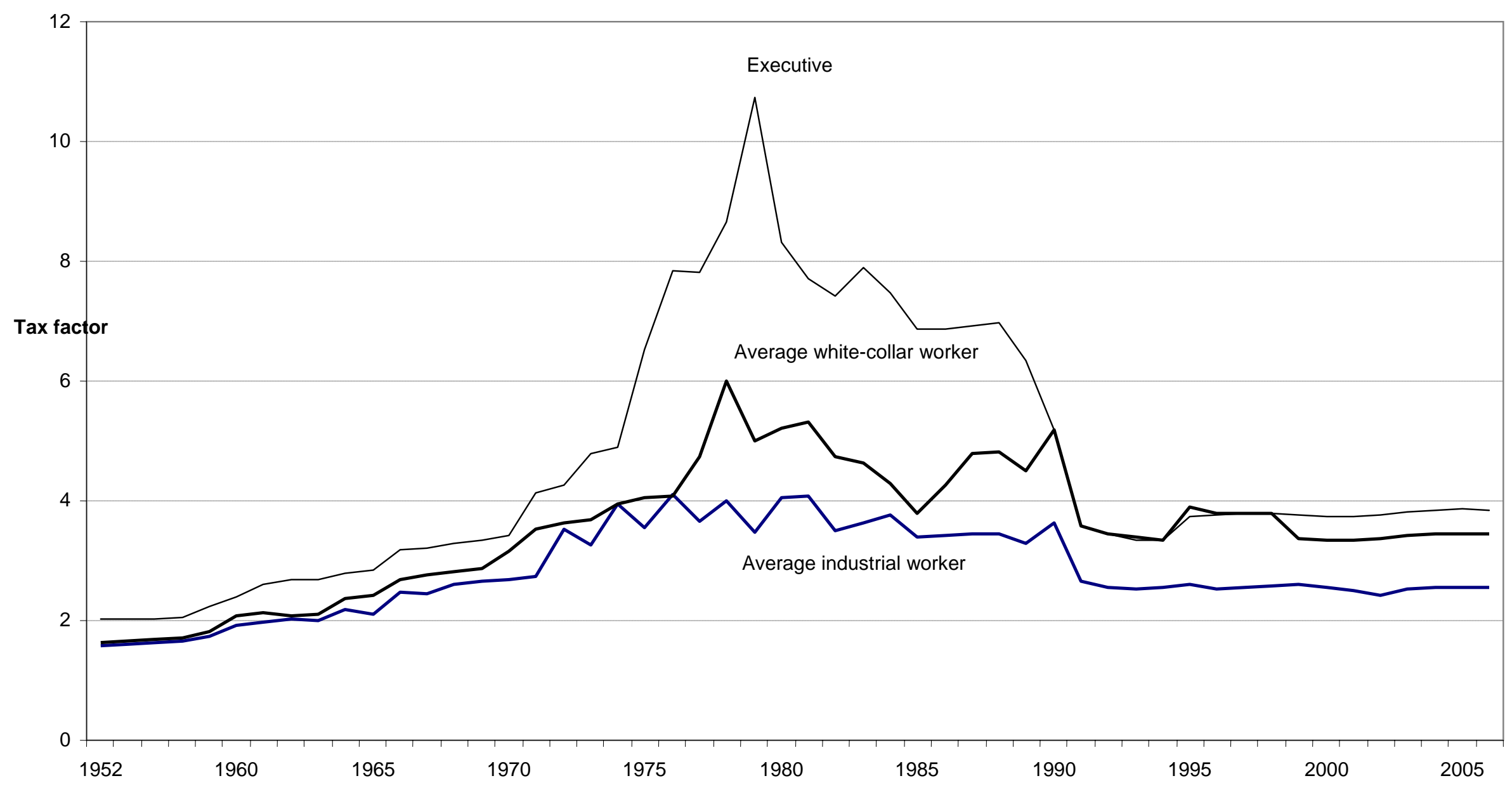




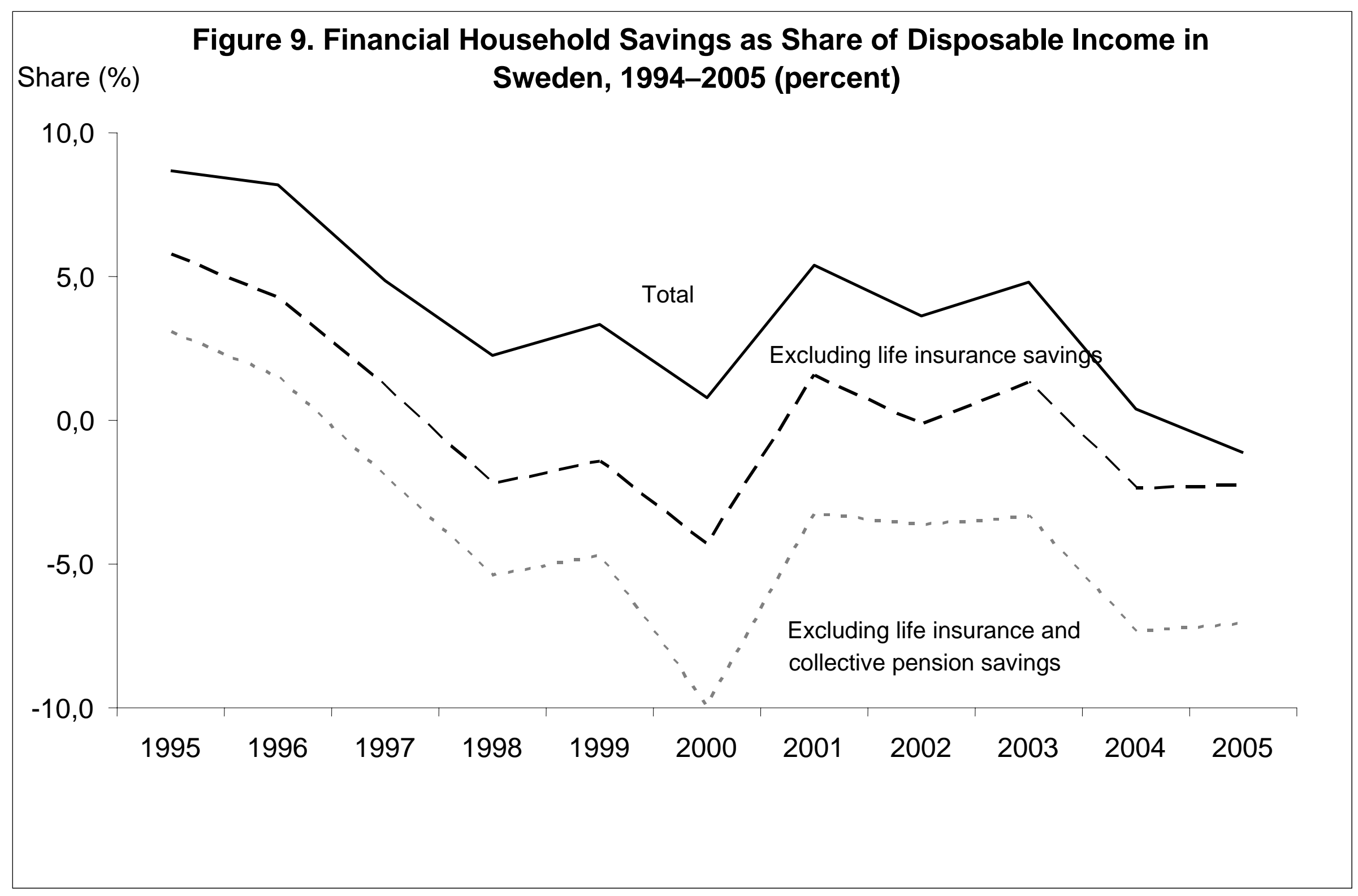

